\title{
Genomic imprints as a model for the analysis of epigenetic stability during assisted reproductive technologies
}

\author{
Michelle M Denomme ${ }^{1,2}$ and Mellissa R W Mann ${ }^{1,2}$ \\ ${ }^{1}$ Departments of Obstetrics and Gynecology, and Biochemistry, Schulich School of Medicine and Dentistry, University \\ of Western Ontario, London, Ontario, Canada and ${ }^{2}$ Children's Health Research Institute, 4th Floor, Victoria Research \\ Laboratories, A4-130a, 800 Commissioners Road E, London, Ontario, Canada N6C 2V5
}

Correspondence should be addressed to M R W Mann at Children's Health Research Institute, 4th Floor, Victoria Research Laboratories; Email: mmann22@uwo.ca

\begin{abstract}
Gamete and early embryo development are important stages when genome-scale epigenetic transitions are orchestrated. The apparent lack of remodeling of differential imprinted DNA methylation during preimplantation development has lead to the argument that epigenetic disruption by assisted reproductive technologies (ARTs) is restricted to imprinted genes. We contend that aberrant imprinted methylation arising from assisted reproduction or infertility may be an indicator of more global epigenetic instability. Here, we review the current literature on the effects of ARTs, including ovarian stimulation, in vitro oocyte maturation, oocyte cryopreservation, IVF, ICSI, embryo culture, and infertility on genomic imprinting as a model for evaluating epigenetic stability. Undoubtedly, the relationship between impaired fertility, ARTs, and epigenetic stability is unquestionably complex. What is clear is that future studies need to be directed at determining the molecular and cellular mechanisms giving rise to epigenetic errors.

Reproduction (2012) 144 393-409
\end{abstract}

\section{Introduction}

Since the first assisted conception in 1978, assisted reproductive technologies (ARTs) have enabled the birth of $\sim 4$ million children from couples with infertility/ subfertility (Zegers-Hochschild et al. 2009). ARTs encompass any treatment modality that is used to improve fertility and establish a pregnancy, including ovarian stimulation, IVF, ICSI, and embryo culture as well as the experimental procedures in vitro oocyte maturation (IVM), and oocyte and ovarian tissue cryopreservation. ARTs can lead to adverse prenatal and postnatal outcomes, including increased risk of intrauterine growth restriction, premature birth, low birth weight, congenital anomalies, and genomic imprinting syndromes (Savage et al. 2011). To reduce these risks, it is paramount to determine which aspects of treatment lead to adverse effects so they may be modified for improved safety. Given that impaired fertility and ARTs alter the gamete and embryo environment, epigenetic instability may be the primary determinant of these suboptimal outcomes.

\section{Genomic imprinting: a model for epigenetic stability}

Epigenetics refers to chromatin modifications that regulate gene activity that are not due to DNA sequence changes (Saitou et al. 2012). DNA methylation and histone modifications are two epigenetic mechanisms that alter the functional state of chromatin, activating or repressing gene expression. Genomic imprinting is a specialized epigenetic mechanism that employs repressive modifications to silence one parental allele, while activating modifications on the other parental allele enable expression (Hirasawa \& Feil 2010). Disruptions in these asymmetric parental states can have severe consequences for growth and development, including Beckwith-Wiedemann syndrome (BWS) and Angelman syndrome (AS) (Hirasawa \& Feil 2010; Box 1).

Gamete and early embryo development are important stages when genome-scale epigenetic transitions are orchestrated (Fig. 1). During oogenesis and spermatogenesis, previous somatic epigenetic modifications are erased, and new sex-specific epigenetic marks are acquired. Paternal DNA methylation acquisition occurs during prenatal stages of spermatogenesis and is completed by birth (Saitou et al. 2012; Fig. 1). During spermiogenesis, protamines replace the majority of histones (Carrell 2012). The resulting effect is tight compaction of chromatin into toroids that are punctuated by histone solenoids (Fig. 2). Histone-containing chromatin, which is situated at spermatogenic, developmental, paternally expressed imprinted gene and microRNA promoters, harbors active histone modifications (H3Ac, H4Ac, and H3K4me2/3) or bivalency 
Box 1 Beckwith-Wiedemann syndrome (BWS) is an overgrowth disorder caused by genetic and epigenetic errors at the KCNQ1OT1 and H19 imprinted domains. ART-conceived BWS children commonly experience maternal KCNQ1OT1 LOM and maternal H19 GOM.

Angelman syndrome (AS) is a neurological disorder that is caused by genetic and epigenetic disturbances at the SNRPN imprinted domain. ART-conceived AS patients often possess maternal SNRPN LOM.

marks (H3K4me3 and H3K27me3) and is hypomethylated, while that at maternally expressed imprinted genes possesses repressive modifications (H3K9me2/3 and DNA methylation) (Hammoud et al. 2009, Brykczynska et al. 2010, Carrell 2012, Nakamura et al. 2012; Box 2). During oogenesis, acquisition of maternal DNA methylation begins comparatively later (puberty) in primary to antral stage follicles and is mostly complete in MII-ovulated oocytes (Saitou et al. 2012; Fig. 1). The MII oocyte genome also possesses repressive histone modifications (H3K9me2/3 and H4K2Ome3) (Lepikhov et al. 2010, Hales et al. 2011).

Following fertilization, genome-scale epigenetic reprogramming occurs again with a switch from a gamete-specific to embryonic state. The pronuclear paternal genome is rapidly and actively demethylated (Fig. 1), undergoes protamine to histone replacement, and further acquires active histone modifications (H4Ac, H3Ac, and H3K4me2/3) (Lepikhov et al. 2010, Hales et al. 2011). By comparison, the maternal pronuclear genome contains active $(\mathrm{H} 4 \mathrm{Ac}, \mathrm{H} 3 \mathrm{Ac}$, and $\mathrm{H} 3 \mathrm{~K} 4 \mathrm{me} 2 / 3)$ and repressive modifications (H3K9me2/3, H3K27me2/ 3 , and $\mathrm{H} 4 \mathrm{~K} 20 \mathrm{me} 3$ ) and becomes passively demethylated during preimplantation development (Fig. 1). By the four-cell stage, the paternal genome acquires repressive histone modifications ( $\mathrm{H} 3 \mathrm{~K} 9 \mathrm{me} 2, \mathrm{H} 3 \mathrm{~K} 27 \mathrm{me} 2$, and $\mathrm{H} 3 \mathrm{~K} 27 \mathrm{me} 3)$ and is globally no longer distinguishable from the maternal genome (Hales et al. 2011). Thus, before and after fertilization, the paternal and maternal genomes possess asymmetric epigenetic modifications.

Differential imprinted DNA methylation is maintained during the preimplantation remodeling period. Its apparent lack of remodeling has lead to the argument that epigenetic disruption by ARTs is restricted to imprinted genes. However, other genes have now been identified with differential gametic DNA methylation that is retained through early preimplantation development (Smallwood et al. 2011, Kobayashi et al. 2012). Furthermore, while genome-wide methylation analyses are limited, altered DNA methylation has been detected at both imprinted and non-imprinted genes in ART-conceived children (Katari et al. 2009), in vitro cultured mouse blastocysts (Wright et al. 2011), and sperm from infertile men (Houshdaran et al. 2007, Pacheco et al. 2011, Aston et al. 2012), as well as globally in two-cell mouse embryos from superovulated mothers and sperm from men with infertility (Shi \& Haaf 2002, Benchaib et al. 2003). Thus, aberrant imprinted methylation may be an indicator of more global epigenetic instability arising from ARTs or underlying infertility. Here, we review the current state of knowledge regarding genomic imprinting following various ARTs and infertility as a model for epigenetic instability. While the literature search was restricted to mouse and

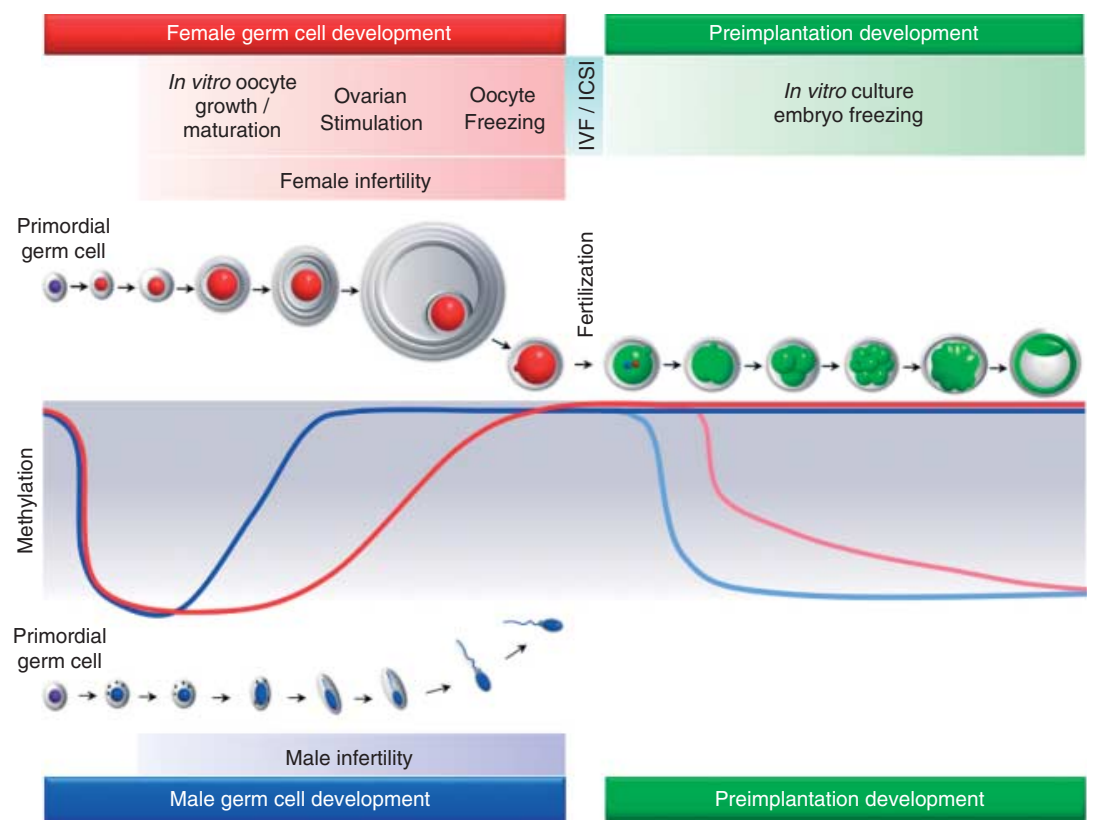

Figure 1 DNA methylation asymmetry during gametogenesis and preimplantation development. Paternal (blue line) and maternal (red line) DNA methylation is erased in primordial germ cells. De novo DNA methylation acquisition occurs earlier in male compared to female germ cell development. Following fertilization, the paternal genome is rapidly and actively demethylated (light blue line) while the maternal genome (light red line) is passively demethylated at each replication cycle. Differential DNA methylation at imprinted genes is protected from demethylation. Infertility/subfertility and various ARTs may cause epigenetic instability at the erasure, acquisition, and maintenance stages. Furthermore, combination of infertility and/or multiple ARTs may impose greater risk for inducing epigenetic errors. 


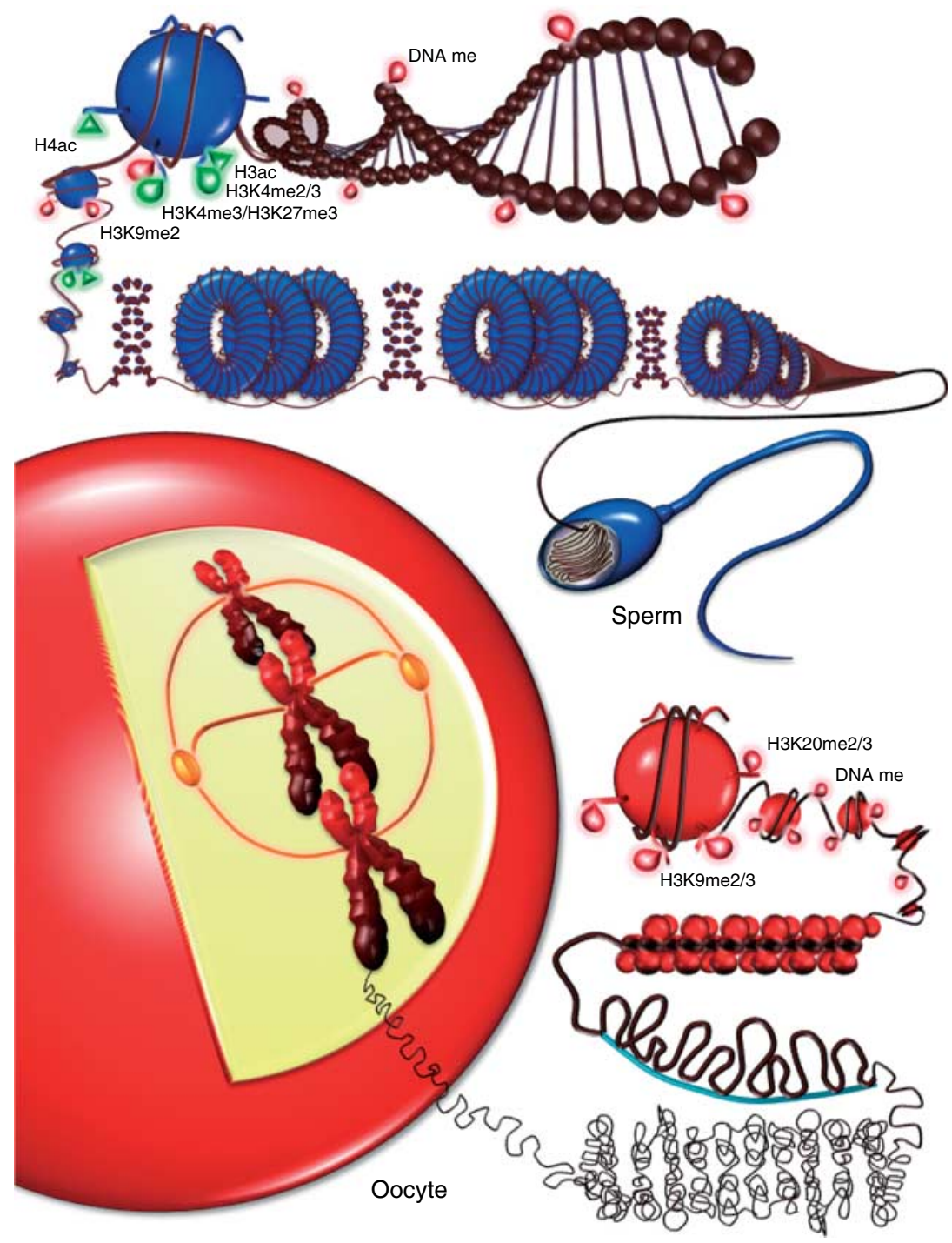

Figure 2 Epigenetic landscape in gametes. In mature sperm, protamines tightly compact chromatin into toroids (90-99\% chromatin) that are punctuated by histone solenoids $(1-10 \%$ chromatin). Sperm DNA is hypermethylated (red; DNA me) except at regions bearing active and bivalent histone modifications. By comparison, histones compact chromatin in the mature oocyte. Chromatin is further condensed into loops that are bound to spindle fibers. Oocyte chromatin is hypermethylated and carries repressive histone modifications. Data from Patrushev \& Minkevich (2008) and Carrell (2012). human, it is important to note that work in other animal models, such as sheep and cattle, support the studies described herein (for example, see Young et al. (2001), Suzuki et al. (2009), Hori et al. (2010), Barboni et al. (2011) and Heinzmann et al. (2011)). Paramount to assisted reproduction is that timing of ARTs coincides with crucial epigenetic events during gametogenesis and early embryogenesis (Fig. 1). Understanding how ARTs cause epigenetic disruption is crucial for maximizing their efficacy and safety.

\section{Manipulations during female germ cell development Ovarian stimulation}

To produce increased oocyte numbers for assisted reproduction, protocols incorporate large gonadotropin doses. Ovarian stimulation has been linked to BWS and AS in ART-conceived children (Chang et al. 2005, Ludwig et al. 2005, Sutcliffe et al. 2006; Table 1). This has lead to investigations of superovulation as a potential imprinting disruptor. Individual mouse 16-cell embryos

Box 2 Histone modifications are posttranslational covalent modifications to histone tails, which have either activating or repressive functions. Histone 3 lysine 9 (H3K9), histone 3 lysine 27 (H3K27), and histone 4 lysine 20 (H4K20) trimethylation (me3) are repressive modifications while histone 4 acetylation (H4Ac) and histone 3 lysine 4 trimethylation ( $\mathrm{H} 3 \mathrm{~K} 4 \mathrm{me} 3$ ) are activating modifications.

DNA methylation is the covalent modification of methyl groups to cytosines within CpG dinucleotides. DNA methylation is typically associated with gene silencing. 
Table 1 Studies on ovarian stimulation and genomic imprinting.

\begin{tabular}{|c|c|c|c|c|c|c|}
\hline Reference & Species & Treatment & Method & Samples & Gene & Observations \\
\hline $\begin{array}{l}\text { Chang et al. } \\
\text { (2005) }\end{array}$ & Human & $\begin{array}{l}\text { Ovarian stimulation; } \\
\text { IVF/ICSI, embryo } \\
\text { culture; Infertility/ } \\
\text { subfertility }\end{array}$ & $\begin{array}{l}\text { Case } \\
\text { series }\end{array}$ & 19/341 BWS ART children & & 2/12 stim only \\
\hline $\begin{array}{l}\text { Ludwig et al. } \\
\qquad(2005)\end{array}$ & Human & $\begin{array}{l}\text { Ovarian stimulation; } \\
\text { Infertility/subfertility }\end{array}$ & $\begin{array}{l}\text { Survey; } \\
\text { COBRA }\end{array}$ & $\begin{array}{l}\text { 16/79 subfertile }+/- \text { ART } \\
\text { children } \\
\text { Blood sample or buccal } \\
\text { smear }\end{array}$ & $S N R P N$ & LOM 4/16 AS children; $1 / 4$ stim only \\
\hline $\begin{array}{l}\text { Sutcliffe et al. } \\
\quad(2006)\end{array}$ & Human & $\begin{array}{l}\text { Ovarian stimulation; } \\
\text { IVF/ICSI; } \\
\text { Infertility/subfertility }\end{array}$ & Survey & 11/79 BWS ART children; & KCNQ1OT1 & LOM 8/11 children; 5 stim only \\
\hline $\begin{array}{l}\text { El Hajj et al. } \\
\qquad(2011)\end{array}$ & Mouse & $7.5 \mathrm{IU}$ eCG/hCG & LD-BMS & $\begin{array}{l}10 \text { individual } 16 \text {-cell } \\
\text { embryos }\end{array}$ & $\begin{array}{l}\text { H19 pat } \\
\text { H19 mat } \\
\text { Snrpn }\end{array}$ & $\begin{array}{l}\text { LOM 2/10 embryos } \\
\text { GOM } 1 / 10 \text { embryos } \\
\text { LOM 2/10 embryos }\end{array}$ \\
\hline $\begin{array}{l}\text { Market-Velker } \\
\text { et al. }(2010 b)\end{array}$ & Mouse & $\begin{array}{l}6.25 \mathrm{IU} \text { (low) or } 10 \mathrm{IU} \\
\text { (high) eCG/hCG }\end{array}$ & BMS & 10 individual blastocysts & $\begin{array}{l}\text { Snrpn } \\
\text { Peg3 } \\
\text { Kcnq1ot1 } \\
\text { H19 mat } \\
\text { H19 pat }\end{array}$ & $\begin{array}{l}\text { LOM } 4 / 10 \text { low, } 9 / 10 \text { high blastocysts } \\
\text { LOM } 4 / 9 \text { low, } 5 / 9 \text { high blastocysts } \\
\text { LOM } 2 / 6 \text { low, } 5 / 9 \text { high blastocysts } \\
\text { LOM } 3 / 10 \text { low, } 7 / 10 \text { high blastocysts } \\
\text { GOM 1/10 low, } 4 / 10 \text { high blastocysts }\end{array}$ \\
\hline $\begin{array}{l}\text { Fortier et al. } \\
\qquad(2008)\end{array}$ & Mouse & $\begin{array}{l}5 \text { IU eCG/hCG; } \\
\text { Blastocysts transfer }\end{array}$ & $\begin{array}{l}\text { BMS, } \\
\text { RT-PCR }\end{array}$ & $\begin{array}{l}36 \text { individual E9.5 embryos } \\
\text { and placentas }\end{array}$ & $\begin{array}{l}\text { Kcnq1ot1 } \\
\operatorname{lgf2}\end{array}$ & $\begin{array}{l}\text { LOIE stim } 3 / 36 \text { emb, } 10 / 36 \text { plac } \\
\text { LOIE stim + transfer } 5 / 32 \text { emb, } 5 / 32 \\
\text { plac } \\
\text { LOM } 0 / 4 \text { emb, } 0 / 4 \text { plac } \\
\text { LOIE stim 5/36 emb, } 22 / 36 \text { plac } \\
\text { LOIE stim + transfer } 13 / 33 \text { emb, } 18 / 33 \\
\text { plac } \\
\text { LOM 0/4 emb, 0/4 plac } \\
\text { LOIE stim } 0 / 36 \text { emb, } 3 / 36 \text { plac } \\
\text { LOIE stim } 2 / 36 \text { plac }\end{array}$ \\
\hline $\begin{array}{l}\text { de Waal et al. } \\
\text { (2012) }\end{array}$ & Mouse & $\begin{array}{l}5 \text { IU eCG/hCG; Culture } \\
\text { two-cell to blastocyst; } \\
\text { Embryo transfer }\end{array}$ & BMS & $\begin{array}{l}8 \text { individual juvenile } \\
\text { liver and brain tissue }\end{array}$ & $\begin{array}{l}\text { H19 } \\
\text { Snrpn } \\
\text { Peg3 }\end{array}$ & $\begin{array}{l}\text { LOM } 1 / 8 \text { livers } \\
\text { LOM } 0 / 8 \text { brain } \\
\text { LOM } 2 / 8 \text { brain }\end{array}$ \\
\hline $\begin{array}{l}\text { Anckaert et al. } \\
\qquad(2009 a)\end{array}$ & Mouse & $5 \mathrm{IU}$ eCG/hCG & BMS & $\begin{array}{l}3 \text { pools, 100-150 MII } \\
\text { oocytes }\end{array}$ & $\begin{array}{l}\text { Snrpn } \\
\text { Peg3 } \\
\text { lgf } 2 r \\
\text { H19 }\end{array}$ & $\begin{array}{l}\text { LOM 0/14 strands } \\
\text { LOM 0/13 strands } \\
\text { LOM 0/17 strands } \\
\text { GOM 0/18 strands }\end{array}$ \\
\hline $\begin{array}{l}\text { Denomme et al. } \\
\quad(2011)\end{array}$ & Mouse & $\begin{array}{l}6.25 \mathrm{IU} \text { (low) or } 10 \mathrm{IU} \\
\text { (high) eCG/hCG }\end{array}$ & BMS & 125 individual MII oocytes & $\begin{array}{l}\text { Snrpn } \\
\text { Peg3 } \\
\text { Kcnq1ot1 } \\
\text { H19 }\end{array}$ & $\begin{array}{l}\text { LOM 0/15 low, 0/15 high oocytes } \\
\text { LOM 0/15 low, 0/17 high oocytes } \\
\text { LOM 0/15 low, } 1 / 16 \text { high oocytes } \\
\text { GOM 0/15 low, 0/17 high oocytes }\end{array}$ \\
\hline Sato et al. (2007) & Mouse & $7.5 \mathrm{IU}$ eCG, $3 \times 5 \mathrm{IU}$ hCG & COBRA & $\begin{array}{l}2 \text { pools, } 30-50 \text { MII oocytes } \\
2 \text { different strains of mice }\end{array}$ & $\begin{array}{l}\text { Peg1 } \\
\text { Kcnq1ot1 } \\
\text { Plagl1 } \\
\text { H19 }\end{array}$ & $\begin{array}{l}\text { No LOM }(94.3 \text { and } 94.0 \%) \\
\text { No LOM }(96.2 \text { and } 93.4 \%) \\
\text { No LOM (96.7 and } 93.4 \%) \\
\text { GOM (37 and } 26 \%)\end{array}$ \\
\hline Sato et al. (2007) & Human & $\begin{array}{l}\text { Ovarian stimulation; } \\
\text { Infertility/subfertility }\end{array}$ & BMS & 10 individual MI oocytes & $\begin{array}{l}\text { PEG1 } \\
\text { H19 }\end{array}$ & $\begin{array}{l}\text { LOM 2/7 MI oocytes } \\
\text { GOM 2/3 Ml oocytes }\end{array}$ \\
\hline $\begin{array}{l}\text { Khoueiry et al. } \\
\qquad(2008)\end{array}$ & Human & $\begin{array}{l}\text { Ovarian stimulation; } \\
\text { Infertility/subfertility }\end{array}$ & BMS & 11 pools, 1-3 MIl oocytes & KCNQ1OT1 & LOM 2/19 strands \\
\hline
\end{tabular}

BMS, bisulfite mutagenesis and sequencing; LD-BMS, limited dilution BMS; COBRA, combined bisulfite-PCR restriction analysis; stim, stimulation; LOM, loss of methylation; GOM, gain of methylation; LOIE, loss of imprinted expression; emb, embryo; plac, placenta.

recovered from superovulated (7.5 IU eCG/hCG) females had paternal H19 loss of methylation (LOM, Box 3) in 2/10 embryos, maternal Snrpn LOM in 2/10 embryos, and maternal $\mathrm{H} 19$ gain of methylation (GOM) in $1 / 10$ embryos. This frequency of imprinting errors was not statistically different from controls (El Hajj et al. 2011). However, as $12-24 \%$ of DNA strands per gene per embryo were recovered, additional perturbations may have been missed. Alternatively, methylation perturbations may be initiated at or after the 16-cell stage, as imprinted methylation errors were present in blastocysts after superovulation. Following low (6.25 IU
eCG/hCG) and high (10 IU eCG/hCG) hormone regimes, we reported imprinted DNA methylation perturbations in individual mouse blastocysts at maternal alleles of Snrpn (LOM, 4/10 low, 9/10 high blastocysts), Peg3 (LOM, 4/9 low, 5/9 high blastocysts), Kcnq1ot1 (LOM, 2/6 low, 5/9 high blastocysts), and H19 (GOM, 1/10 low, 4/10 high blastocysts) (Market-Velker et al. 2010b). As paternal H19 LOM was also seen (3/10 low, 7/10 high blastocysts), we concluded that superovulation impaired both imprint acquisition in oocytes and imprint maintenance in early embryos in a dose-dependent manner. Moreover, multilocus imprinted methylation 
Box 3 LOM and GOM. In our literature evaluation, we defined loss and gain of methylation as having a $50 \%$ or greater change in DNA methylation; sporadic methylation loss or gain was not included.

perturbations were greater in the high hormone group (10/10 blastocysts) compared with the low hormone (4/10 blastocysts) and control groups (1/10 blastocysts). At midgestation, mouse conceptuses produced via low hormone (5 IU eCG/hCG) treatment showed altered allelic expression of Snrpn, H19, and Igf2, but not Kcnq1ot1 in placentas but not in embryos (Fortier et al. 2008). Additionally, 3/8 superovulation-derived mice (5 IU eCG/hCG) showed LOM at H19 and Peg3, but not Snrpn, in brain and liver tissues (de Waal et al. 2012). These studies indicate that superovulation can lead to imprinting maintenance errors.

As ovarian stimulation is administered during oogenesis, it may also disrupt imprint acquisition. Five studies have examined the effects of ovarian stimulation on imprint acquisition in oocytes. Following low hormone treatment (5 IU eCG/hCG), methylation of Snrpn, Peg3, Igf2r, and $H 19$ was unaffected in mouse MII oocyte pools (14-18 DNA strands analyzed per gene) (Anckaert et al. 2009a). Likewise, we found no effect of superovulation on imprinted DNA methylation acquisition in 15-17 individual mouse MII oocytes using low (6.25 IU eCG/hCG) and high (10 IU eCG/hCG) hormone dosages at Snrpn, Kcnq1ot1 (LOM 1/16 high oocytes), Peg3, and H19 (Denomme et al. 2011). These results contrast with mouse oocytes collected after sequential hormone treatment ( 3 days $7.5 \mathrm{IU}$ eCG/ 1 day $5 \mathrm{IU}$ hCG) where H19 exhibited GOM (26-37\%) in pooled MII oocytes, although normal methylation acquisition was present at Peg1 (Mest), Kcnq1ot1, and Plagl1 (Zac1) (Sato et al. 2007). As zona pellucidae were not removed from pooled oocytes, H19 GOM may be the result of cumulus cell contamination. Following ovarian stimulation in humans, individual MI oocytes showed PEG1 LOM (2/7 oocytes) and H19 GOM (2/3 oocytes) (Sato et al. 2007), and in the last study, pooled MII oocytes exhibited maternal KCNQ1OT1 LOM (2/19 strands) (Khoueiry et al. 2008). With respect to the human MI oocyte study, PEG1 may still be in its acquisition phase. Alternatively, human oocytes may be more prone to epigenetic errors and/or encounter more stressors, such as multiple hormone administration, advanced maternal age, and inherent infertility. Considering the frequency of epigenetic perturbations in blastocysts compared with oocytes, ovarian stimulation may have greater adverse impact on maternal factors required for imprint maintenance than on imprint acquisition. Future studies should be directed toward larger numbers of human oocytes as well as identification of maternal effect genes.

\section{In vitro oocyte maturation}

Follicle culture and IVM is an alternative, experimental procedure to obtain large oocyte numbers. Long-term IVM is initiated with preantral follicles while short-term IVM begins with GV/MI oocytes, which are then cultured to MII oocytes. Disparate results have been reported for the effects of IVM on genomic imprinting in the mouse. Using long-term IVM and supraphysiological recombinant $\mathrm{FSH}(\mathrm{rFSH})$, imprinted methylation perturbations were observed in pools of GV oocytes with H19 GOM (1/7 pools), Peg1 LOM (1/7 pools), and Igf $2 r$ LOM (6/7 pools) (Kerjean et al. 2003; Table 2). By comparison, normal $H 19$ (0/39 strands) and Igf2r methylation (0/15 strands) was found in pooled GV oocytes following longterm IVM with physiological $r F S H$, although LOM was observed at Snrpn (2/47 DNA strands) (Trapphoff et al. 2010). Additionally, independent studies with long-term IVM using physiological or supraphysiological rFSH reported normal Snrpn, Igf2r, Peg3, and H19 methylation in MII oocyte pools (Anckaert et al. 2009a, 2009b, 2010). Furthermore, toxic ammonium levels (through addition of ammonium acetate or mineral oil overlay) and low methyl donor levels in IVM medium had no effect on Snrpn, Igf2r, and H19 methylation (Anckaert et al. 2009b, 2010). In humans, using the short-term protocol on oocytes from stimulated women, H19 GOM was found in 2/10 MII oocyte pools (Borghol et al. 2006) and at 3/34 DNA strands in MII oocyte pools (Al-Khtib et al. 2011). KCNQ1OT1 LOM was also observed in 5/23 and 2/37 DNA strands from IVM MII oocyte pools (Khoueiry et al. 2008, Al-Khtib et al. 2011). This contrasts with short-term IVM MII oocytes that had normal SNRPN (three single oocytes), KCNQ1OT1 (four single oocytes), and MEG3 (GTL2) (three pools of two oocytes) methylation (Geuns et al. 2003, 2007a, 2007b). In the above studies, where zona pellucidae were not removed, there is the possibility of cumulus cell contamination. Overall, the long-term IVM does not appear to pose high risk for imprinted acquisition errors. Further investigations will be required to delineate the incidence and consequent effects of both long-term and short-term IVM.

\section{Cryopreservation and vitrification}

Given the complications of multi-fetal pregnancies, current clinical practice is to transfer fewer embryos and cryopreserve remaining embryos. Technologies are also advancing for oocyte and ovarian tissue cryogenics. Four studies have investigated cryogenic effects on 
Table 2 Studies on in vitro oocyte maturation and genomic imprinting.

\begin{tabular}{|c|c|c|c|c|c|c|}
\hline Reference & Species & Treatment & Method & Samples & Gene & Observations \\
\hline Kerjean et al. (2003) & Mouse & $\begin{array}{l}\text { Long protocol; } \\
100 \mathrm{IU} / \mathrm{l} \mathrm{rFSH}\end{array}$ & BMS & 7 pools, 5-8 GV oocytes & $\begin{array}{l}\text { H19 } \\
\text { Peg1 } \\
\text { Igf2r }\end{array}$ & $\begin{array}{l}\text { GOM } 1 / 7 \text { pools } \\
\text { LOM } 1 / 7 \text { pools } \\
\text { LOM } 6 / 7 \text { pools }\end{array}$ \\
\hline Trapphoff et al. (2010) & Mouse & $\begin{array}{l}\text { Long protocol; } \\
10 \mathrm{IU} / \mathrm{l} \text { rFSH }\end{array}$ & BMS & 7-11 pools, 10 GV oocytes & $\begin{array}{l}\text { Snrpn } \\
\text { H19 } \\
\text { Igf2r }\end{array}$ & $\begin{array}{l}\text { LOM } 2 / 47 \text { strands } \\
\text { GOM 0/39 strands } \\
\text { LOM 0/15 strands }\end{array}$ \\
\hline \multirow[t]{4}{*}{ Anckaert et al. (2009a) } & Mouse & $\begin{array}{l}\text { Long protocol; } \\
10 \mathrm{IU} / \mathrm{l} \mathrm{rFSH} \text { or } \\
100 \mathrm{IU} / \mathrm{I} \mathrm{rFSH}\end{array}$ & BMS & $\begin{array}{l}\text { 4-8 pools, 100-150 MII } \\
\text { oocytes }\end{array}$ & Snrpn & $\begin{array}{l}\text { LOM } 0 / 22 \text { strands } \\
10 \mathrm{IU} / \mathrm{l}, 0 / 20 \\
\text { strands } 100 \mathrm{IU} / \mathrm{I}\end{array}$ \\
\hline & & & & & $\lg 2 r$ & $\begin{array}{l}\text { LOM 0/10 strands } \\
10 \mathrm{IU} / \mathrm{l}\end{array}$ \\
\hline & & & & & Peg3 & $\begin{array}{l}\text { LOM } 0 / 15 \text { strands } \\
10 \mathrm{IU} / \mathrm{l}, 0 / 21 \\
\text { strands } 100 \mathrm{IU} / \mathrm{I}\end{array}$ \\
\hline & & & & & H19 & $\begin{array}{l}\text { GOM } 0 / 28 \text { strands } \\
10 \mathrm{IU} / \mathrm{l}, 0 / 25 \\
\text { strands } 100 \mathrm{IU} / \mathrm{I}\end{array}$ \\
\hline Anckaert et al. (2009b) & Mouse & $\begin{array}{l}\text { Long protocol; } 10 \mathrm{IU} / \mathrm{I} \\
\text { rFSH; } 500 \mu \mathrm{M} \\
\text { ammonium acetate and } \\
\text { mineral oil overlay }\end{array}$ & BMS & 2-4 pools, $100 \mathrm{MII}$ oocytes & $\begin{array}{l}\text { Snrpn } \\
\text { lgf2r } \\
\text { H19 }\end{array}$ & $\begin{array}{l}\text { LOM 0/26 strands } \\
\text { LOM 0/50 strands } \\
\text { GOM 0/45 strands }\end{array}$ \\
\hline Anckaert et al. (2010) & Mouse & $\begin{array}{l}\text { Long protocol; } \\
10 \mathrm{IU} / \mathrm{I} \text { rFSH; Low } \\
\text { methyl donor levels }\end{array}$ & BMS & 3 pools, 100 MII oocytes & $\begin{array}{l}\text { Snrpn } \\
\text { lgf2r } \\
\text { H19 }\end{array}$ & $\begin{array}{l}\text { LOM 0/36 strands } \\
\text { LOM 0/29 strands } \\
\text { GOM 0/36 strands }\end{array}$ \\
\hline Borghol et al. (2006) & Human & $\begin{array}{l}\text { Short protocol; } \\
\text { Ovarian stimulation; } \\
\text { Infertility/subfertility }\end{array}$ & BMS & 10 pools, $1-8$ MII oocytes & H19 & GOM 2/10 pools \\
\hline Al-Khtib et al. (2011) & Human & $\begin{array}{l}\text { Short protocol; } \\
\text { Ovarian stimulation; } \\
\text { Infertility/subfertility }\end{array}$ & BMS & $\begin{array}{l}16 \text { pools, } 1-3 \text { MII oocytes } \\
20 \text { individual MII oocytes }\end{array}$ & $\begin{array}{l}\text { H19 } \\
\text { KCNQ1OT1 }\end{array}$ & $\begin{array}{l}\text { GOM 3/34 strands } \\
\text { LOM 2/37 strands }\end{array}$ \\
\hline Khoueiry et al. (2008) & Human & $\begin{array}{l}\text { Short protocol; } \\
\text { Ovarian stimulation; } \\
\text { Infertility/subfertility }\end{array}$ & BMS & 12 pools, $1-6$ MII oocytes & KCNQ1OT1 & LOM 5/23 strands \\
\hline Geuns et al. (2003) & Human & $\begin{array}{l}\text { Short protocol; } \\
\text { Ovarian stimulation; } \\
\text { Infertility/subfertility }\end{array}$ & BMS & 3 individual MII oocytes & $S N R P N$ & LOM 0/3 oocytes \\
\hline Geuns et al. (2007a) & Human & $\begin{array}{l}\text { Short protocol; } \\
\text { Ovarian stimulation; } \\
\text { Infertility/subfertility }\end{array}$ & BMS & 3 pools, 2 MII oocytes & MEG3 & GOM 0/3 pools \\
\hline Geuns et al. (2007b) & Human & $\begin{array}{l}\text { Short protocol; } \\
\text { Ovarian stimulation; } \\
\text { Infertility/subfertility }\end{array}$ & BMS & 4 individual MII oocytes & KCNQ1OT1 & LOM 1/4 oocytes \\
\hline
\end{tabular}

BMS, bisulfite mutagenesis and sequencing; LOM, loss of methylation; GOM, gain of methylation.

imprinted methylation (Table 3). Ultra-rapid vitrification of mouse preantral follicles followed by long-term IVM to GV oocytes led to Snrpn LOM (1/50 strands) but not Igf2 $r$ LOM (0/15 strands) or H19 GOM (0/58 strands) in pooled vitrified oocytes (Trapphoff et al. 2010). In the second study, mice produced following whole ovary cryopreservation maintained normal $\mathrm{H} 19$ and Kcnq1ot 1 methylation ratios (Sauvat et al. 2008). Unfortunately, averaging methylation levels from three tissues from 5 to 36 mice may have obscured imprinting defects in individual mice. In humans, vitrification of GV oocytes followed by short-term IVM resulted in H19 GOM in MII oocyte pools (5/29 strands), although this was not significantly different from IVM-only MII oocytes (3/34 strands). Finally, analysis of 17 human vitrified-IVM MII oocytes showed KCNQ1OT1 LOM (1/28 strands), which again was not significantly different from
20 IVM-only MII oocytes (2/37 strands) (Al-Khtib et al. 2011). Overall, these studies suggest that freezing does not impart greater risk than IVM alone. However, more studies are required to understand the effects of cryogenic technologies on genomic imprinting.

\section{Manipulations to mature oocytes and sperm IVF and ICSI}

Once retrieved, oocytes are fertilized via IVF (oocyte insemination in culture) or ICSI (sperm injection into oocyte). Many studies have reported an increased prevalence of IVF and ICSI (3- to 14-fold) among children with BWS compared with those in the general population (DeBaun et al. 2003, Gicquel et al. 2003, Maher et al. 2003, Halliday et al. 2004, Chang et al. 2005, Rossignol et al. 2006, Sutcliffe et al. 2006, Lim et al. 2009; Table 4). 
Table 3 Studies on cryopreservation and vitrification and genomic imprinting.

\begin{tabular}{|c|c|c|c|c|c|c|}
\hline Reference & Species & Treatment & Method & Samples & Gene & Observations \\
\hline $\begin{array}{l}\text { Trapphoff et al. } \\
\text { (2010) }\end{array}$ & Mouse & $\begin{array}{l}\text { Vitrification of pre-antral } \\
\text { follicles; Long protocol } \\
\text { IVM; } 10 \mathrm{IU} / \mathrm{l} \mathrm{rSH}\end{array}$ & BMS & 6-12 pools, 10 GV oocytes & $\begin{array}{l}\text { Snrpn } \\
\text { H19 } \\
\text { Igf2r }\end{array}$ & $\begin{array}{l}\text { LOM } 1 / 50 \text { strands } \\
\text { GOM 0/58 strands } \\
\text { LOM 0/15 strands }\end{array}$ \\
\hline $\begin{array}{l}\text { Sauvat et al. } \\
\quad(2008)\end{array}$ & Mouse & $\begin{array}{l}\text { Whole ovary; } \\
\text { cryopreservation }\end{array}$ & Southern & $\begin{array}{l}\text { Kidney, muscle, and tongue } \\
\text { tissues from } 5 \text { to } 36 \text { mice }\end{array}$ & Kenq1ot1 & $\begin{array}{l}\text { No GOM in mean } \\
\text { methylation levels } \\
\text { No LOM in mean } \\
\text { methylation levels }\end{array}$ \\
\hline $\begin{array}{l}\text { Al-Khtib et al. } \\
\text { (2011) }\end{array}$ & Human & $\begin{array}{l}\text { Vitrification of GV oocytes; } \\
\text { Short protocol IVM; } \\
\text { Infertility/subfertility }\end{array}$ & BMS & $\begin{array}{l}12 \text { pools, } 1-3 \text { MII oocytes } \\
17 \text { individual MII oocytes }\end{array}$ & $\begin{array}{l}\text { H19 } \\
\text { KCNQ1OT1 }\end{array}$ & $\begin{array}{l}\text { GOM } 5 / 29 \text { strands } \\
\text { LOM } 1 / 28 \text { strands }\end{array}$ \\
\hline
\end{tabular}

BMS, bisulfite mutagenesis and sequencing; LOM, loss of methylation; GOM, gain of methylation.

Many of these BWS children display maternal KCNQ1OT1 LOM. Similarly, AS children born after both IVF and ICSI have a greater prevalence of SNRPN imprinting defects than AS children in the general population (Cox et al. 2002, Orstavik et al. 2003, Ludwig et al. 2005). Moreover, in IVF and ICSI BWS children, KCNQ1OT1 LOM is coincident with SNRPN, PEG1, PLAGL1, and IGF2R LOM, indicating that multiple imprinting defects may be present in these children (Rossignol et al. 2006, Lim et al. 2009).

Conversely, examination of ART populations for the prevalence of imprinting syndromes or imprinting defects has produced conflicting results. Of 1680 IVF and $4372 \mathrm{ICSI}$ children, none had an imprinting disorder (Lidegaard et al. 2005). In a second study of 1524 IVF and ICSI children, 174 had phenotypic features of an imprinting disorder and of the 47 children clinically assessed, one had BWS, three had BWS-like symptoms (no KCNQ1OT1 LOM), and one had AS-like symptoms (no SNRPN LOM) (Bowdin et al. 2007). With respect to imprinting defects, one ICSI- and two IVF-conceived children out of 18 possessed KCNQ1OT1 LOM (Gomes et al. 2009); one ICSI child out of 18 had L3MBTL LOM (Feng et al. 2011); and three ICSI children out of 61 had H19 LOM (Shi et al. 2011). In addition, greater intra- and interindividual H19 GOM was present in 45 in vitro-conceived compared to 56 in vivoconceived children (Turan et al. 2010). In another study, higher PEG1 methylation levels were found in 35 IVF-conceived compared to 77 ICSI-conceived and 73 spontaneously conceived children, although no differences in mean methylation levels were identified at nine other imprinted genes (Tierling et al. 2010). By comparison, normal imprinted methylation was detected at H19, KCNQ1OT1, and SNRPN in 34 IVF- and 32 ICSI-conceived children (Oliver et al. 2012); at SNRPN in 92 ICSI children (Manning et al. 2000); and at SNRPN in 32 IVF and 45 ICSI placentas from newborns (Wong et al. 2011). While these later studies argue that the absolute risk of imprinting disorders in ARTsconceived children is small, it should be noted that many of these studies were performed on buccal and peripheral blood samples by methods that detect 1 or 2 CpGs per gene. In fact, tissue-specific effects of ICSI have been reported with 1/6 ICSI-conceived mice displaying $\mathrm{H} 19 \mathrm{LOM}$ in brain, muscle, and liver compared with 1/6 mice each having Peg3 LOM and Snrpn LOM in brain only (de Waal et al. 2012).

At earlier developmental stages, IVF and ICSI have been implicated in ART-induced epigenetic instability. IVF resulted in significantly more individual mouse blastocysts with aberrant H19 methylation (16/36) compared with embryo production without IVF (0/15) or superovulation alone (0/26) (Fauque et al. 2007). In humans, H19 LOM was identified in five IVF and one ICSI blastocysts out of 32 (Chen et al. 2010). Finally, compared to high-grade control blastocysts, 8/21 ICSI developmentally delayed/morphologically compromised embryos harbored paternal H19 LOM and 1/21 ICSI delayed/compromised embryos possessed maternal H19 GOM (Ibala-Romdhane et al. 2011). Further studies are required to determine the incidence of early developmental and tissue-specific imprinting perturbations induced by IVF and ICSI as well as how these technologies lead to imprinting defects in resulting embryos and offspring.

\section{Manipulations during preimplantation development}

\section{In vitro embryo culture}

Following IVF or ICSI, embryos are cultured to the eightcell or blastocyst stage before transfer into the mother. A query of in vitro culture media used in ART-conceived BWS children revealed that multiple media systems were employed, including human tubal fluid (HTF) medium, Cook's sequential medium, preimplantation 1 (P1) medium, and growth 1 and 2 (G1/G2) medium, suggesting that media type per se is not the root factor in generating ART-induced perturbations (Chang et al. 2005; Table 5). Instead, culture environment may be suboptimal, compromising imprint maintenance. The first evidence of this came in 1995 when cultured mouse embryos displayed biallelic H19 expression in postimplantation extraembryonic tissues (Sasaki et al. 1995). 


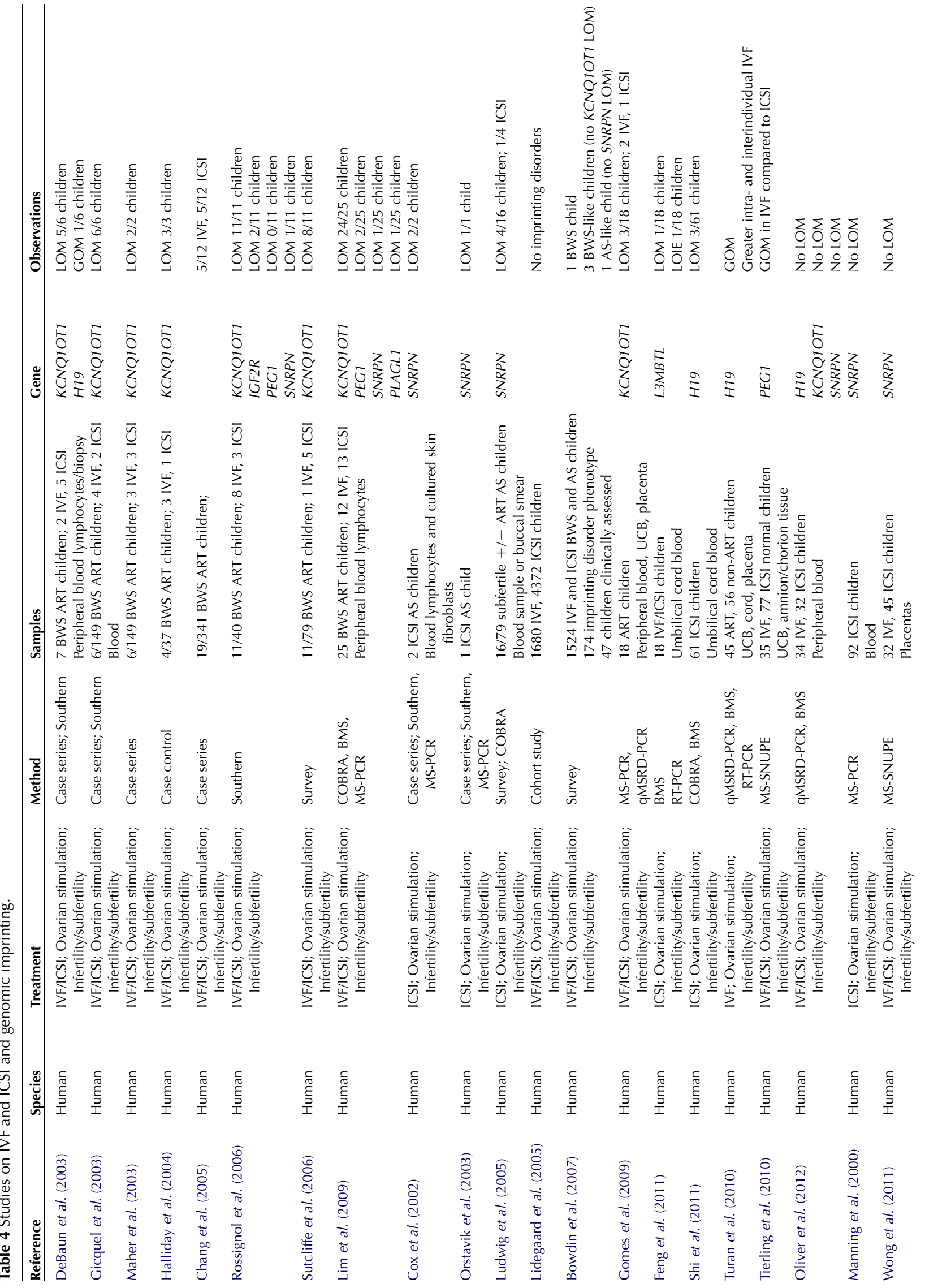




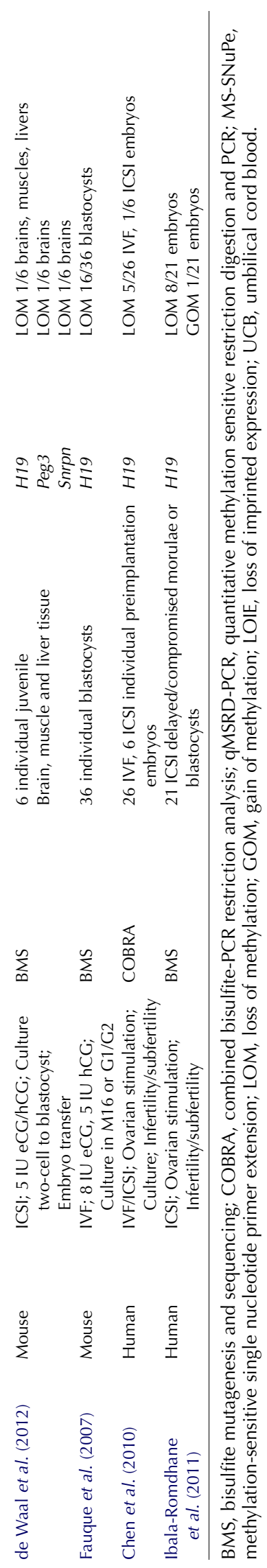

Other studies have since shown aberrant imprinting in cultured embryos. In pooled blastocysts, Whitten's but not potassium simplex optimized medium plus amino acids (KSOMaa) cultured embryos exhibited biallelic H19 expression (Doherty et al. 2000). At the individual blastocyst level, 63\% (24/38) of Whitten's and 14\% (3/21) of KSOMaa-cultured embryos displayed biallelic H19 expression, which correlated with H19 LOM (Whitten's 59\% and KSOMaa 77\% paternal methylation) (Mann et al. 2004). Snrpn LOM was also greater in embryos cultured in Whitten's (40\% maternal methylation) than in KSOMaa ( $82 \%$ maternal methylation) medium. We further compared five commercial media (KSOMaa, Global, HTF, P1/Multiblast, and G1.5/G2.5) with Whitten's medium. While all culture media were suboptimal at maintaining imprinted methylation, some media better maintained H19 (KSOMaa 75\%, Global $75 \%$, and other media $52-65 \%$ mean paternal methylation), Snrpn (KSOMaa 73\%, Global 72\%, and other media 54-65\% mean maternal methylation), and Peg3 methylation (KSOMaa 93\%, HTF 85\%, Global 77\%, P1/Multiblast $75 \%$, and other media 50-54\% mean maternal methylation) (Market-Velker et al. 2010a). Similarly, culture in M16 medium (8/19 blastocysts) caused greater H19 LOM than G1.2/G2.2 (6/17 blastocysts) (Fauque et al. 2007). HTF culture produced 8/23 mouse blastocysts with aberrant $\mathrm{H} 19$ expression ( $\mathrm{Li}$ et al. 2005). In humans, H19 LOM occurred in 19\% of human embryos cultured in cleavage medium (Chen et al. 2010). Postimplantation, aberrant H19, Ascl2, Snrpn, and Peg3 expression and H19 and Snrpn LOM occurred in placentas but rarely in fetuses subjected to Whitten's or KSOMaa preimplantation culture (Mann et al. 2004).

Like other ARTs, imprinting errors occur stochastically in response to suboptimal culture in that not every embryo and not every imprinted locus possesses imprinting defects. To address a possible origin for these stochastic events, we examined imprinted methylation in blastocysts with different developmental rates in culture. We found that a greater number of embryos with fast rates of development had Snrpn and H19 LOM (8/11 and 5/10 respectively) compared with those that developed slower in culture (4/10 and 3/11 respectively) (Market Velker et al. 2012). Future studies are required to determine when epigenetic instability is arising during in vitro development and through which mechanism(s), as well as why some embryos are more sensitive to the adverse effects of culture.

\section{Inherent infertility}

\section{Impaired fertility and imprinting defects}

The increased incidence of imprinting disorders in the ART population has led to the question of whether infertility predisposes embryos to imprinting errors. In an examination of 16 AS children born to subfertile 


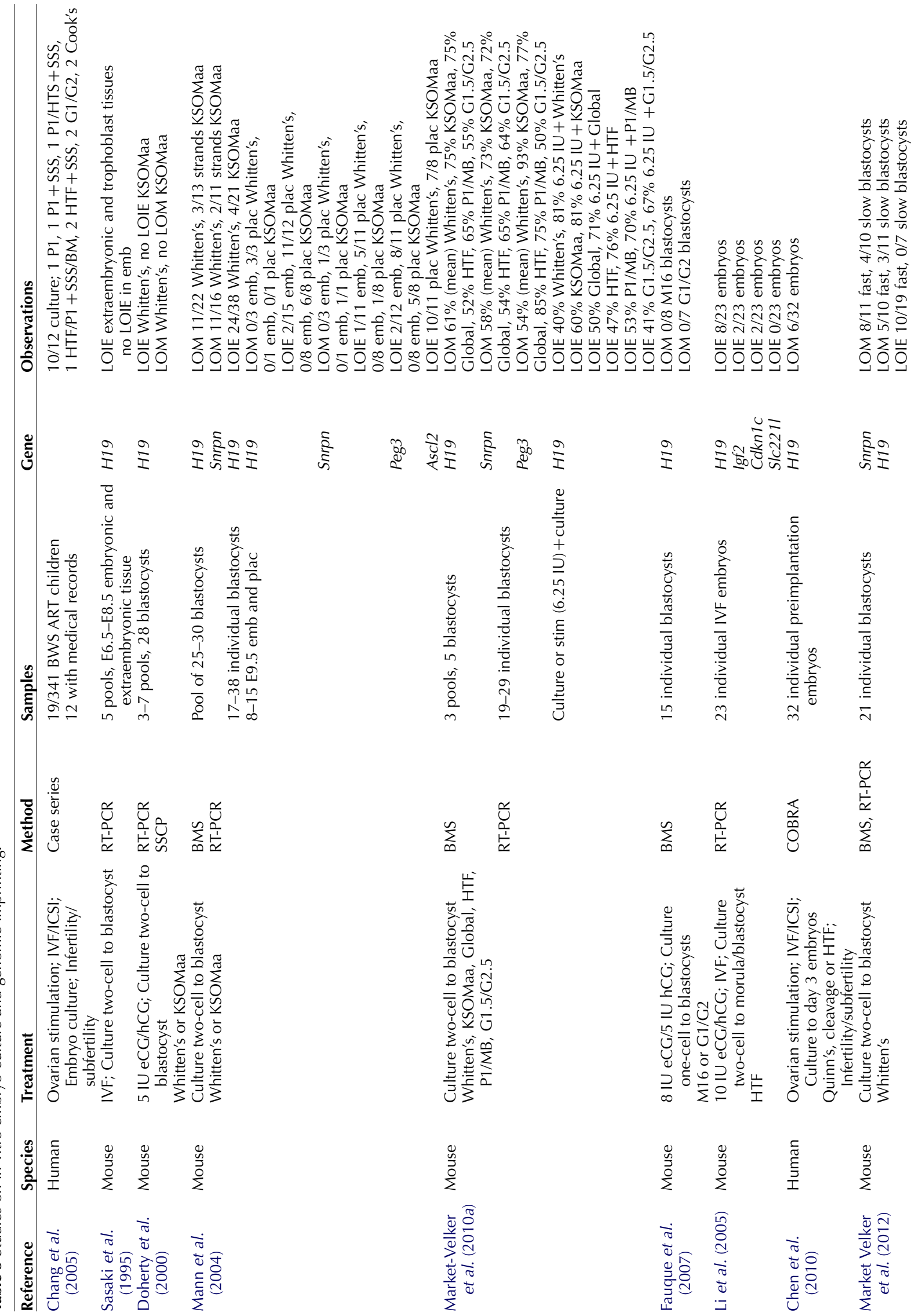




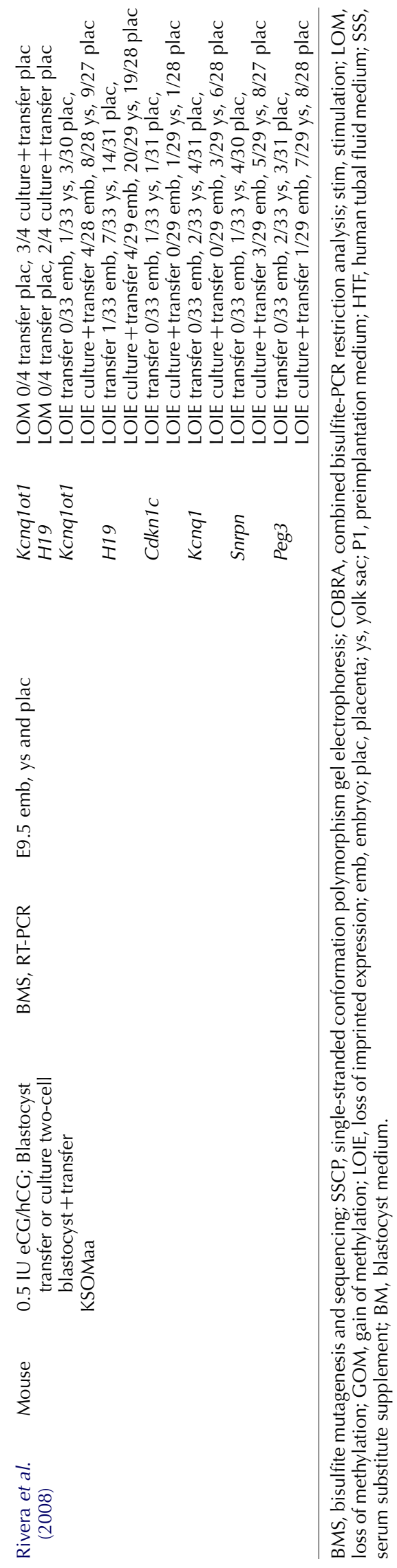

couples, four were caused by sporadic imprinting defects, including two from parents who conceived without assistance (Ludwig et al. 2005). In addition, a case of two BWS children in the same family, one born via ARTs and the other born naturally, suggests that impaired fertility may be associated with mechanisms leading to imprinting disorders (Strawn et al. 2010).

\section{Female infertility/subfertility}

The most common variable influencing natural conception in modern society is reproductive age. Advanced maternal age ( $>35$ years) is directly related to a decline in fertility with a reduced oocyte reserve and poor oocyte quality (Liu \& Case 2011). In a Dutch study evaluating ARTs and parental infertility, $6.3 \%$ of AS, $8.5 \%$ of BWS, and $2.1 \%$ of total children were conceived via ARTs, while $6.3 \%$ of AS, $8.5 \%$ of BWS, and $3.5 \%$ of total children were born to subfertile families without ARTs (Doornbos et al. 2007; Table 6). The same relative risk of AS and BWS in subfertile couples with and without ARTs indicates that the increased prevalence of imprinting disorders can be explained by compromised fertility. Significantly, advanced maternal age was increased in AS and BWS mothers compared with the general population, suggesting that advanced maternal age may decrease fertility and increase the risk of imprinting disorders. In mouse, advanced maternal age compromised postimplantation development, although no age-related change in imprinted DNA methylation was detected at Snrpn, U2af1rs1, Kcnq1ot1, Igf2r, Peg1, and H19 in blastocysts and midgestation conceptuses (Lopes et al. 2009). As a means of simulating infertility, our group used connexin37 deletion mice to determine whether compromised gap junctional communication between the oocyte and the cumulus cells would disrupt de novo methylation acquisition in growing oocytes (Denomme et al. 2012). Connexin 37 deficiency resulted in loss or delayed methylation acquisition at the late-acquiring gene Peg1, but not at Snrpn and Peg3, suggesting that stored methyl donors or other metabolites normally transported from granulosa cells to the oocyte may have been exhausted during oocyte growth. To understand the etiology of epigenetic instability in infertility, further studies are required to determine when imprinting errors occur (oocyte or embryo development; young or aged oocytes), as well as the type of female factor infertility and the molecular mechanisms leading to imprinting perturbations. Furthermore, to delineate the risk of epigenetic errors resulting from ARTs vs infertility, investigations are required on embryos and children from couples seeking ARTs in the absence of infertility such as for preimplantation genetic diagnosis and same-sex couples. 


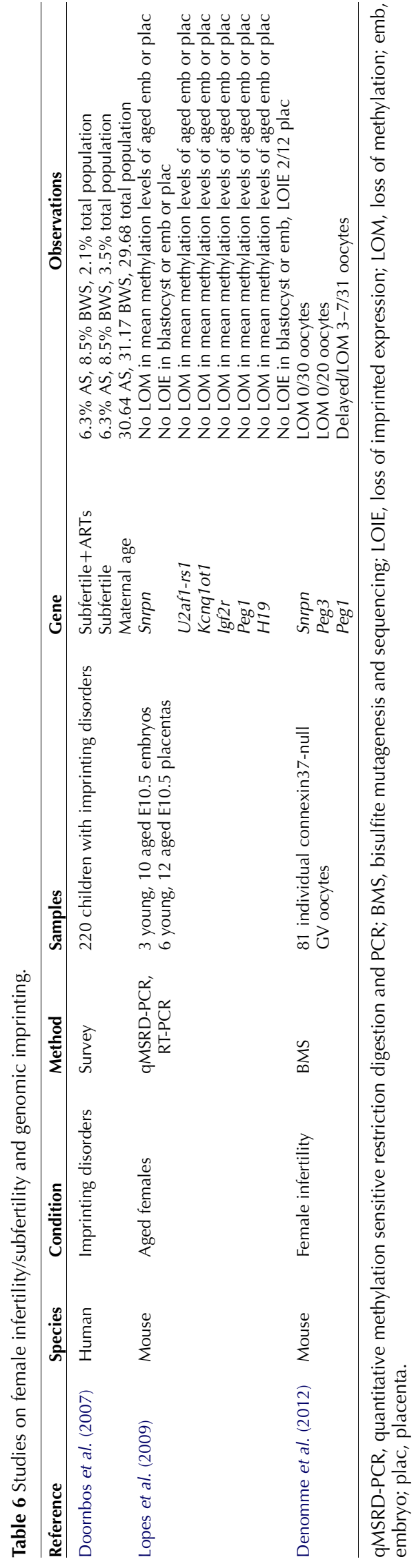

\section{Male infertility/subfertility}

Male infertility can result from irregular sperm morphology (teratozoospermia), poor motility (asthenozoospermia), low sperm count (oligozoospermia), or absence of sperm (azoospermia) (Krausz 2011). Numerous studies have examined imprinted methylation in sperm from infertile men, with most focusing on oligozoospermia. Analysis of sperm from 79 men with normozoospermia, eight men with moderate oligozoospermia, and ten men with severe oligozoospermia showed greater imprinted methylation perturbations in oligozoospermia compared with normozoospermia at H19 (LOM, 0/79, 1/8, and 3/10), MEG3 (LOM, 5/79, 2/8, and 4/10), PEG1 (GOM, 7/79, $2 / 8$, and $3 / 10$ ), KCNQ1OT1 (GOM, 3/79, 0/8, and $1 / 10$ ), PEG3 (GOM, 4/79, 1/8, and 0/10), and SNRPN (GOM, 1/79, 2/8, and 1/10) (Kobayashi et al. 2007; Table 7). Furthermore, multilocus perturbations were greater in moderate $(2 / 8 ; 25 \%)$ and severe oligozoospermic sperm (5/10; 50\%) compared with normozoospermic sperm (5/79; 6.3\%). Similarly, imprinting perturbations were present in sperm from $0 / 5$ men with normozoospermia, 0/5 men with mild, 2/5 men with moderate (one H19, one H19 plus PEG1), 4/5 men with severe (two H19, two $P E G 1)$, and $2 / 5$ men with very severe oligozoospermia (one PEG1, one H19 plus PEG1) (Marques et al. 2008). In a third study, methylation perturbations were again greater in oligozoospermic men compared with normozoospermic men at H19 (LOM, 1/204 normal, 1/61 moderate, and 8/57 severe), MEG3 (LOM, 2/201 normal, 6/56 moderate, and 15/55 severe), ZDBF2 (LOM, 0/119 normal, 1/60 moderate, and 2/47 severe), PEG1 (GOM, 7/129 normal, 4/29 moderate, and 5/23 severe), PEG3 (GOM, 2/127 normal, 1/25 moderate, and $1 / 21$ severe), ZACN (GOM, 0/120 normal, 1/56 moderate, and 4/61 severe), SNRPN (GOM, 0/124 normal, 4/60 moderate, and 2/61 severe), and KCNQ1OT1 (GOM, 1/95 normal, $0 / 7$ moderate, and $1 / 9$ severe) (Sato et al. 2011). Multilocus methylation perturbations were greater in men with severe $(10 / 22 ; 45 \%)$ and moderate $(2 / 11 ; 18 \%)$ oligozoospermia than in normozoospermic men $(3 / 14$; $21 \%)$. These studies contrast with a lack of SNRPN methylation errors in sperm from 17 normozoospermic, 17 moderate oligozoospermic, and 16 severe oligozoospermic men (Manning et al. 2001). Finally, the prevalence of $\mathrm{H} 19 \mathrm{LOM}$ was greater in sperm from oligozoospermic men (3/3 moderate, $6 / 6$ severe, and 5/6 very severe) compared with men with teratozoospermia (1/9) and astheno-teratozoospemia (0/7) (Boissonnas et al. 2010). Altogether, these results indicate that moderate-to-severe oligozoospermia is associated with imprinting errors.

Testicular sperm from men with azoospermia has also been examined for imprinting errors. H19 LOM occurred in 5/10 men with obstructive azoospermia compared with $1 / 5$ men with nonobstructive 
Table 7 Studies on male infertility/subfertility and genomic imprinting.

\begin{tabular}{|c|c|c|c|c|c|}
\hline Reference & Species & Method & Samples & Gene & Observations \\
\hline $\begin{array}{l}\text { Kobayashi et al. } \\
\text { (2007) }\end{array}$ & Human & COBRA, BMS & Ejaculated sperm & $\begin{array}{l}\text { H19 } \\
\text { MEG3 } \\
\text { PEG1 } \\
\text { KCNQ1OT1 } \\
\text { PLAGL1 } \\
\text { PEG3 } \\
\text { SNRPN }\end{array}$ & $\begin{array}{l}\text { LOM 0/79 norm, } 1 / 8 \text { mod, } 3 / 10 \text { severe } \\
\text { LOM } 5 / 79 \text { norm, } 2 / 8 \text { mod, } 4 / 10 \text { severe } \\
\text { GOM } 7 / 79 \text { norm, } 2 / 8 \text { mod, } 3 / 10 \text { severe } \\
\text { GOM } 3 / 79 \text { norm, } 0 / 8 \text { mod, } 1 / 10 \text { severe } \\
\text { GOM } 0 / 79 \text { norm, } 0 / 8 \text { mod, } 3 / 10 \text { severe } \\
\text { GOM } 4 / 79 \text { norm, } 1 / 8 \text { mod, } 0 / 10 \text { severe } \\
\text { GOM } 1 / 79 \text { norm, } 2 / 8 \text { mod, } 1 / 10 \text { severe }\end{array}$ \\
\hline $\begin{array}{l}\text { Marques et al. } \\
(2008)\end{array}$ & Human & BMS & Ejaculated sperm & $\begin{array}{l}\text { H19 } \\
\text { PEG1 }\end{array}$ & $\begin{array}{l}\text { LOM } 0 / 5 \text { norm, } 0 / 5 \text { mild, } 2 / 5 \text { mod, } 2 / 5 \text { severe, } \\
1 / 5 \text { very severe } \\
\text { GOM } 0 / 5 \text { norm, } 0 / 5 \text { mild, } 1 / 5 \text { mod, } 2 / 5 \text { severe } \\
2 / 5 \text { very severe }\end{array}$ \\
\hline Sato et al. (2011) & Human & $\mathrm{BPL}$ & Ejaculated sperm & $\begin{array}{l}\text { H19 } \\
\text { MEG3 } \\
\text { ZDBF2 } \\
\text { PEG1 } \\
\text { PEG3 } \\
\text { PLAGL1 } \\
\text { SNRPN } \\
\text { KCNQ1OT1 }\end{array}$ & $\begin{array}{l}\text { LOM } 1 / 204 \text { norm, } 1 / 61 \text { mod, } 8 / 57 \text { severe } \\
\text { LOM } 2 / 201 \text { norm, } 6 / 56 \text { mod, } 15 / 55 \text { severe } \\
\text { LOM 0/119 norm, } 1 / 60 \text { mod, } 2 / 47 \text { severe } \\
\text { GOM } 7 / 129 \text { norm, } 4 / 29 \text { mod, } 5 / 23 \text { severe } \\
\text { GOM 2/127 norm, } 1 / 25 \text { mod, } 1 / 21 \text { severe } \\
\text { GOM 0/120 norm, } 1 / 56 \text { mod, } 4 / 61 \text { severe } \\
\text { GOM 0/124 norm, } 4 / 60 \text { mod, } 2 / 61 \text { severe } \\
\text { GOM } 1 / 95 \text { norm, } 0 / 7 \text { mod, } 1 / 9 \text { severe }\end{array}$ \\
\hline $\begin{array}{l}\text { Manning et al. } \\
(2001)\end{array}$ & Human & BMS & Ejaculated sperm & SNRPN & LOM 0/17 norm, 0/17 mod, 0/16 severe \\
\hline $\begin{array}{l}\text { Boissonnas et al. } \\
\text { (2010) }\end{array}$ & Human & BMS & Ejaculated sperm & $H 19$ & $\begin{array}{l}\text { LOM } 3 / 3 \text { mod, } 6 / 6 \text { severe, } 5 / 6 \text { very severe, } \\
1 / 9 \text { terato, } 0 / 7 \text { astheno }\end{array}$ \\
\hline $\begin{array}{l}\text { Minor et al. } \\
\quad(2011)\end{array}$ & Human & BMS & Testicular sperm & $\begin{array}{l}\text { H19 } \\
\text { PEG1 } \\
\text { MEG3 }\end{array}$ & $\begin{array}{l}\text { LOM } 5 / 10 \text { obs, } 1 / 5 \text { nonobs, } 5 / 17 \text { vas } \\
\text { GOM } 0 / 10 \text { obs, } 0 / 5 \text { nonobs, } 2 / 17 \text { vas } \\
\text { LOM } 0 / 10 \text { obs, } 0 / 5 \text { nonobs, } 0 / 17 \text { vas }\end{array}$ \\
\hline $\begin{array}{l}\text { Kobayashi et al. } \\
\text { (2009) }\end{array}$ & Human & COBRA, BMS & $\begin{array}{l}78 \text { 6-9 week abortuses } \\
\text { Trophoblastic villi } \\
11 \text { paired abortus } \\
\text { - ejaculated sperm }\end{array}$ & $\begin{array}{l}\text { H19 } \\
\text { MEG3 } \\
\text { PEG1 } \\
\text { KCNQ1OT1 } \\
\text { PLAGL1 } \\
\text { PEG3 } \\
\text { SNRPN } \\
\text { XIST }\end{array}$ & $\begin{array}{l}\text { LOM 6/78 samples } \\
\text { LOM 2/78 samples } \\
\text { GOM } 1 / 78 \text { samples } \\
\text { GOM } 4 / 78 \text { samples } \\
\text { GOM } 1 / 78 \text { samples } \\
\text { GOM } 1 / 78 \text { samples } \\
\text { GOM 0/78 samples } \\
\text { GOM } 5 / 78 \text { samples }\end{array}$ \\
\hline $\begin{array}{l}\text { Hammoud et al. } \\
\text { (2010) }\end{array}$ & Human & BMS & Frozen ejaculated sperm & $\begin{array}{l}\text { KCNQ1OT1 } \\
\text { PEG1 }\end{array}$ & $\begin{array}{l}\text { GOM 0/7 norm, } 3 / 8 \text { oligo, } 2 / 9 \text { protamine } \\
\text { GOM 0/5 norm, } 3 / 10 \text { oligo, } 1 / 10 \text { protamine }\end{array}$ \\
\hline
\end{tabular}

BMS, bisulfite mutagenesis and sequencing; COBRA, combined bisulfite-PCR restriction analysis; BPL, bisulfite polymerase chain reaction Luminex; norm, normozoospermia; mild, mild oligozoospermia; mod, moderate oligozoospermia; severe, severe oligozoospermia; very severe, very severe oligozoospermia; oligo, oligozoospermia; terato, teratozoospermia; astheno, astheno-teratozoospermia; obs, obstructive azoospermia; nonobs, nonobstructive azoospermia; vas, vasectomy reversal; protamine, abnormal histone-protamine incorporation; LOM, loss of methylation; GOM, gain of methylation.

azoospermia (Minor et al. 2011). Interestingly, testicular sperm from previously fertile men undergoing vasectomy reversal also showed imprinting errors with 5/17 men possessing PEG1 GOM and/or H19 LOM. Methylation perturbations in these previously fertile men may relate to advanced paternal age. Alternatively, obstruction may generate an aberrant testicular environment, accounting for greater perturbations in vasectomy reversal and obstructive azoospermic men.

The important question is whether sperm-imprinting errors are transmitted to offspring. Analysis of abortuses from 78 males with normozoospermia and moderateto-severe oligozoospermia identified 17 samples $(22 \%)$ with abnormal DNA methylation (six H19 LOM, two MEG3 LOM, one PEG1 GOM, four KCNQ1OT1 GOM, one PLAGL1 GOM, one PEG3 GOM, O SNRPN GOM, and five XIST GOM), of which six were from normozoospermic and 11 from oligozoospermic males (Kobayashi et al. 2009). Of the 11 paired samples, seven $(41 \%)$ showed methylation errors in both sperm and abortus (five H19 LOM, one MEG3 LOM, and one H19 plus MEG3 LOM), indicating that imprinting errors can be transmitted to fetuses. However, of these pairs, half the abortuses had a complete LOM and half were mosaic for methylation perturbations. As imprinting errors from sperm would expect to be transmitted to all cells in abortuses, it is also unclear how mosaic methylation patterns arise in offspring following fertilization. Additionally, it is unclear which epigenetic mechanisms would lead to both a LOM at paternally methylated genes and a GOM at normally unmethylated, paternally expressed genes in the same sperm sample.

Finally, imprinting errors have been investigated in sperm with abnormal histone to protamine transition. Imprinting errors occurred almost equally in sperm from men with abnormal protamine incorporation (2/9 KCNQ1OT1 GOM and 1/10 PEG1 GOM) and oligozoospermic men (3/8 KCNQ1OT1 GOM and 3/10 PEG1 GOM) compared with fertile men (0/7 KCNQ1OT1 
GOM and 0/5 PEG1 GOM) (Hammoud et al. 2010). As abnormal histone to protamine transition can result in a loss of $\mathrm{H} 3 \mathrm{~K} 4 \mathrm{me} 3$ at paternally expressed genes and a gain of $\mathrm{H} 3 \mathrm{~K} 4 \mathrm{me} 3$ at paternally silent genes (Carrell 2012), this may be indicative of chromatin structural changes that produce corresponding GOM and LOM in sperm, and possibly in fetuses and offspring. Further investigations are required to determine whether imprinting errors in sperm originate from incomplete erasure of DNA methylation marks, perturbations in imprinted methylation acquisition, DNA methylation maintenance errors, and/or aberrant chromatin packaging/protamine-histone incorporation. As well, studies are required to identify potential mechanisms for inheritance of imprinting errors in fetuses and offspring from infertile males.

\section{Discussion}

\section{Complexity of multiple arts and infertility}

The question of gamete and embryo predisposition to ART-induced epigenetic defects is of critical importance. As multiple ARTs are employed, it is difficult to discern the origin of imprinting anomalies in human embryos. In the mouse, superovulation in combination with embryo culture increased the number of blastocysts with biallelic H19 expression above embryo culture alone (Market-Velker et al. 2010a), as well superovulation, embryo culture, and blastocyst transfer generated a greater proportion of conceptuses with aberrant imprinted expression compared with superovulation and embryo transfer without culture (Rivera et al. 2008). These and other studies indicate that combined ART treatments can produce greater numbers of embryos with imprinting perturbations. With this caveat in mind, the literature suggests that ovarian stimulation, IVM, and cryopreservation do not greatly impact DNA methylation acquisition but instead give rise to imprinting maintenance perturbations. Furthermore, as IVF, ICSI, and embryo culture disrupt imprinting maintenance, we propose that ARTs converge on a common imprinting regulatory pathway.

Human embryos produced via ARTs are also the product of underlying infertility/subfertility. This has lead to questions regarding the origin of epigenetic instability, i.e. whether underlying infertility/subfertility compromises epigenetic integrity in gametes/embryos, whether gamete/embryo manipulations cause epigenetic instability, or whether a combination of subfertility and ARTs leads to epigenetic disruption. The relationship between impaired fertility, ARTs, and epigenetic stability is unquestionably complex. However, the possibility exists that ARTs and infertility may disrupt the same biological pathways that lead to epigenetic instability. If this is the case, perturbations induced by infertility/subfertility may be exacerbated by gamete or embryo manipulation, similar to combined ART treatments.
Finally, while the caveats of multiple ARTs and infertility are recognized, it should be noted that further complexity is compounded by a number of methodological and biological issues. These include varied methylation assays (in some cases limited to 1-2 CpGs), nonallelic analyses, lack of controls, small sample sizes, cumulus cell contamination, oocyte, embryo, and tissue pooling (mask or inflate rare epigenetic errors), the use of discarded/failed human reproductive samples (non-fertilized oocytes and fragmented embryos), age (preimplantation, midgestation, and childhood), and type of tissue (embryo, placenta, and peripheral blood cells), type of infertility, as well as social determinants (parental age, smoking, and obesity). To gain further insight into the causes of epigenetic instability arising from ARTs and infertility, future studies need to take these important issues into consideration.

\section{Pathways leading to epigenetic instability}

Multiple avenues of investigation are required to delineate the effects of infertility/subfertility and ARTs on epigenetic gene regulation. Foremost, studies are required to determine the molecular and cellular mechanisms giving rise to epigenetic errors. This includes the identification of maternal factors needed for epigenetic regulation during embryo development. Acceleration of oocyte maturation or recovery of atretic oocytes by superovulation, adaptation to suboptimal IVM culture, or stress induced by cryopreservation can affect the oocyte's ability to synthesize and store sufficient amounts of maternal factors (Li et al. 2010). Four maternal effect proteins have been identified that protect imprinted genes from demethylation during preimplantation development. The oocyte-specific DNA methyltransferase 10 maintains imprinted methylation in eight-cell embryos (Cirio et al. 2008). Zinc finger protein 57 together with KAP1 protects imprinted genes from (possibly passive) demethylation ( $\mathrm{Li}$ et al. 2008, Messerschmidt et al. 2012). Developmental pluripotency-associated 3 (STELLA/PGC7) protects imprinted genes from demethylation by binding to $\mathrm{H} 3 \mathrm{~K} 9 \mathrm{me} 2$, inhibiting the active conversion of 5-methylcytosine to 5-hydroxymmethylcytosine (Nakamura et al. 2012). Investigation of these and other maternal effect products is required to determine whether their synthesis and storage are affected by oocyte manipulation and/or infertility and whether their ART-induced misregulation leads to epigenetic instability in resulting embryos. We are also intrigued by the possibility that perturbations in bivalency marks in sperm histones of infertile men may lead to epigenetic errors in developing embryos. Further studies are required to investigate perturbations in histone modifications following infertility and ARTs in gametes and embryos. Finally, genome-scale studies are needed to determine the scope of epigenetic 
instability at nonimprinted genes in gametes and embryos as a result of infertility/subfertility and ARTs.

Assisted reproduction will continue to be a critical medical intervention for infertile couples. To maximize the safety of these ARTs, it is imperative to understand how mechanisms involved in epigenetic regulation are affected by impaired fertility and ART treatments. This will lead to the development of screening procedures to identify at-risk embryos as well as preventative measures that will reduce the occurrence of epigenetic perturbations.

\section{Declaration of interest}

The authors declare that there is no conflict of interest that could be perceived as prejudicing the impartiality of the research reported.

\section{Funding}

M M Denomme was supported by a CIHR Training Program in Reproduction, Early Development and the Impact on Health (REDIH) Graduate Scholarship.

\section{References}

Al-Khtib M, Perret A, Khoueiry R, Ibala-Romdhane S, Blachere T, Greze C, Lornage J \& Lefevre A 2011 Vitrification at the germinal vesicle stage does not affect the methylation profile of $\mathrm{H} 19$ and KCNQ1OT1 imprinting centers in human oocytes subsequently matured in vitro. Fertility and Sterility 95 1955-1960. (doi:10.1016/j.fertnstert.2011.02.029)

Anckaert E, Adriaenssens T, Romero S, Dremier S \& Smitz J 2009a Unaltered imprinting establishment of key imprinted genes in mouse oocytes after in vitro follicle culture under variable follicle-stimulating hormone exposure. International Journal of Developmental Biology $\mathbf{5 3}$ 541-548. (doi:10.1387/ijdb.082619ea)

Anckaert E, Adriaenssens T, Romero S \& Smitz J 2009b Ammonium accumulation and use of mineral oil overlay do not alter imprinting establishment at three key imprinted genes in mouse oocytes grown and matured in a long-term follicle culture. Biology of Reproduction $\mathbf{8 1}$ 666-673. (doi:10.1095/biolreprod.109.076810)

Anckaert E, Romero S, Adriaenssens T \& Smitz J 2010 Effects of low methyl donor levels in culture medium during mouse follicle culture on oocyte imprinting establishment. Biology of Reproduction 83 377-386. (doi:10.1095/biolreprod.109.082164)

Aston KI, Punj V, Liu L \& Carrell DT 2012 Genome-wide sperm deoxyribonucleic acid methylation is altered in some men with abnormal chromatin packaging or poor in vitro fertilization embryogenesis. Fertility and Sterility 97 285-292. (doi:10.1016/j.fertnstert.2011.11.008)

Barboni B, Russo V, Cecconi S, Curini V, Colosimo A, Garofalo ML, Capacchietti G, Di Giacinto O \& Mattioli M 2011 In vitro grown sheep preantral follicles yield oocytes with normal nuclearepigenetic maturation. PLOS ONE 6 e27550. (doi:10.1371/journal. pone.0027550)

Benchaib M, Ajina M, Lornage J, Niveleau A, Durand P \& Guerin JF 2003 Quantitation by image analysis of global DNA methylation in human spermatozoa and its prognostic value in in vitro fertilization: a preliminary study. Fertility and Sterility 80 947-953. (doi:10.1016/ S0015-0282(03)01151-8)

Boissonnas CC, Abdalaoui HE, Haelewyn V, Fauque P, Dupont JM, Gut I, Vaiman D, Jouannet P, Tost J \& Jammes H 2010 Specific epigenetic alterations of IGF2-H19 locus in spermatozoa from infertile men. European Journal of Human Genetics 18 73-80. (doi:10.1038/ejhg. 2009.117)
Borghol N, Lornage J, Blachere T, Sophie Garret A \& Lefevre A 2006 Epigenetic status of the H19 locus in human oocytes following in vitro maturation. Genomics 87 417-426. (doi:10.1016/j.ygeno. 2005.10.008)

Bowdin S, Allen C, Kirby G, Brueton L, Afnan M, Barratt C, KirkmanBrown J, Harrison R, Maher ER \& Reardon W 2007 A survey of assisted reproductive technology births and imprinting disorders. Human Reproduction 22 3237-3240. (doi:10.1093/humrep/dem268)

Brykczynska U, Hisano M, Erkek S, Ramos L, Oakeley EJ, Roloff TC, Beisel C, Schubeler D, Stadler MB \& Peters AH 2010 Repressive and active histone methylation mark distinct promoters in human and mouse spermatozoa. Nature Structural \& Molecular Biology 17 679-687. (doi:10.1038/nsmb.1821)

Carrell DT 2012 Epigenetics of the male gamete. Fertility and Sterility 97 267-274. (doi:10.1016/j.fertnstert.2011.12.036)

Chang AS, Moley KH, Wangler M, Feinberg AP \& Debaun MR 2005 Association between Beckwith-Wiedemann syndrome and assisted reproductive technology: a case series of 19 patients. Fertility and Sterility 83 349-354. (doi:10.1016/j.fertnstert.2004.07.964)

Chen SL, Shi XY, Zheng HY, Wu FR \& Luo C 2010 Aberrant DNA methylation of imprinted $\mathrm{H} 19$ gene in human preimplantation embryos. Fertility and Sterility 94 2356-2358, 2358.e1. (doi:10.1016/j.fertnstert. 2010.01.120)

Cirio MC, Martel J, Mann M, Toppings M, Bartolomei M, Trasler J \& Chaillet JR 2008 DNA methyltransferase 1o functions during preimplantation development to preclude a profound level of epigenetic variation. Developmental Biology 324 139-150. (doi:10.1016/j.ydbio. 2008.09.015)

Cox GF, Burger J, Lip V, Mau UA, Sperling K, Wu BL \& Horsthemke B 2002 Intracytoplasmic sperm injection may increase the risk of imprinting defects. American Journal of Human Genetics 71 162-164. (doi:10.1086/341096)

DeBaun MR, Niemitz EL \& Feinberg AP 2003 Association of in vitro fertilization with Beckwith-Wiedemann syndrome and epigenetic alterations of LIT1 and H19. American Journal of Human Genetics 72 156-160. (doi:10.1086/346031)

Denomme MM, Zhang L \& Mann MR 2011 Embryonic imprinting perturbations do not originate from superovulation-induced defects in DNA methylation acquisition. Fertility and Sterility 96 734-738.e2. (doi:10.1016/j.fertnstert.2011.06.055)

Denomme MM, White CR, Gillio-Meina C, Macdonald WA, Deroo BJ, Kidder GM \& Mann MR 2012 Compromised fertility disrupts Peg1 but not Snrpn and Peg3 imprinted methylation acquisition in mouse oocytes. Frontiers in Genetics 3 129. (doi:10.3389/fgene. 2012.00129)

Doherty AS, Mann MR, Tremblay KD, Bartolomei MS \& Schultz RM 2000 Differential effects of culture on imprinted H19 expression in the preimplantation mouse embryo. Biology of Reproduction 62 1526-1535. (doi:10.1095/biolreprod62.6.1526)

Doornbos ME, Maas SM, McDonnell J, Vermeiden JP \& Hennekam RC 2007 Infertility, assisted reproduction technologies and imprinting disturbances: a Dutch study. Human Reproduction 22 2476-2480. (doi:10.1093/humrep/dem172)

El Hajj N, Trapphoff T, Linke M, May A, Hansmann T, Kuhtz J, Reifenberg K, Heinzmann J, Niemann H, Daser A et al. 2011 Limiting dilution bisulfite (pyro)sequencing reveals parent-specific methylation patterns in single early mouse embryos and bovine oocytes. Epigenetics 6 1176-1188. (doi:10.4161/epi.6.10.17202)

Fauque $P$, Jouannet $P$, Lesaffre C, Ripoche MA, Dandolo L, Vaiman D \& Jammes H 2007 Assisted Reproductive Technology affects developmental kinetics, H19 Imprinting Control Region methylation and H19 gene expression in individual mouse embryos. BMC Developmental Biology 7 116. (doi:10.1186/1471-213X-7-116)

Feng C, Tian S, Zhang Y, He J, Zhu XM, Zhang D, Sheng JZ \& Huang HF 2011 General imprinting status is stable in assisted reproductionconceived offspring. Fertility and Sterility 96 1417-1423.e9. (doi:10.1016/ j.fertnstert.2011.09.033)

Fortier AL, Lopes FL, Darricarrere N, Martel J \& Trasler JM 2008 Superovulation alters the expression of imprinted genes in the midgestation mouse placenta. Human Molecular Genetics 17 1653-1665. (doi:10.1093/hmg/ddn055) 
Geuns E, De Rycke M, Van Steirteghem A \& Liebaers I 2003 Methylation imprints of the imprint control region of the SNRPN-gene in human gametes and preimplantation embryos. Human Molecular Genetics 12 2873-2879. (doi:10.1093/hmg/ddg315)

Geuns E, De Temmerman N, Hilven P, Van Steirteghem A, Liebaers I \& De Rycke M 2007a Methylation analysis of the intergenic differentially methylated region of DLK1-GTL2 in human. European Journal of Human Genetics 15 352-361. (doi:10.1038/sj.ejhg.5201759)

Geuns E, Hilven P, Van Steirteghem A, Liebaers I \& De Rycke M 2007 b Methylation analysis of KvDMR1 in human oocytes. Journal of Medical Genetics 44 144-147. (doi:10.1136/jmg.2006.044149)

Gicquel C, Gaston V, Mandelbaum J, Siffroi JP, Flahault A \& Le Bouc Y 2003 In vitro fertilization may increase the risk of Beckwith-Wiedemann syndrome related to the abnormal imprinting of the KCN1OT gene. American Journal of Human Genetics 72 1338-1341. (doi:10.1086/ 374824)

Gomes MV, Huber J, Ferriani RA, Amaral Neto AM \& Ramos ES 2009 Abnormal methylation at the KvDMR1 imprinting control region in clinically normal children conceived by assisted reproductive technologies. Molecular Human Reproduction 15 471-477. (doi:10.1093/ molehr/gap038)

Hales BF, Grenier L, Lalancette C \& Robaire B 2011 Epigenetic programming: from gametes to blastocyst. Birth Defects Research. Part A, Clinical and Molecular Teratology 91 652-665. (doi:10.1002/bdra. 20781)

Halliday J, Oke K, Breheny S, Algar E \& Amor DJ 2004 BeckwithWiedemann syndrome and IVF: a case-control study. American Journal of Human Genetics 75 526-528. (doi:10.1086/423902)

Hammoud SS, Nix DA, Zhang H, Purwar J, Carrell DT \& Cairns BR 2009 Distinctive chromatin in human sperm packages genes for embryo development. Nature 460 473-478. (doi:10.1038/nature08162)

Hammoud SS, Purwar J, Pflueger C, Cairns BR \& Carrell DT 2010 Alterations in sperm DNA methylation patterns at imprinted loci in two classes of infertility. Fertility and Sterility 94 1728-1733. (doi:10.1016/ j.fertnstert.2009.09.010)

Heinzmann J, Hansmann T, Herrmann D, Wrenzycki C, Zechner U, Haaf T \& Niemann H 2011 Epigenetic profile of developmentally important genes in bovine oocytes. Molecular Reproduction and Development 78 188-201. (doi:10.1002/mrd.21281)

Hirasawa R \& Feil R 2010 Genomic imprinting and human disease. Essays in Biochemistry 48 187-200. (doi:10.1042/bse0480187)

Hori N, Nagai M, Hirayama M, Hirai T, Matsuda K, Hayashi M, Tanaka T, Ozawa T \& Horike S 2010 Aberrant CpG methylation of the imprinting control region KvDMR1 detected in assisted reproductive technologyproduced calves and pathogenesis of large offspring syndrome. Animal Reproduction Science 122 303-312. (doi:10.1016/j.anireprosci.2010. 09.008)

Houshdaran S, Cortessis VK, Siegmund K, Yang A, Laird PW \& Sokol RZ 2007 Widespread epigenetic abnormalities suggest a broad DNA methylation erasure defect in abnormal human sperm. PLOS ONE 2 e1289. (doi:10.1371/journal.pone.0001289)

Ibala-Romdhane S, Al-Khtib M, Khoueiry R, Blachere T, Guerin JF \& Lefevre A 2011 Analysis of H19 methylation in control and abnormal human embryos, sperm and oocytes. European Journal of Human Genetics 19 1138-1143. (doi:10.1038/ejhg.2011.99)

Katari S, Turan N, Bibikova M, Erinle O, Chalian R, Foster M, Gaughan JP, Coutifaris C \& Sapienza C 2009 DNA methylation and gene expression differences in children conceived in vitro or in vivo. Human Molecular Genetics 18 3769-3778. (doi:10.1093/hmg/ddp319)

Kerjean A, Couvert P, Heams T, Chalas C, Poirier K, Chelly J, Jouannet P, Paldi A \& Poirot C 2003 In vitro follicular growth affects oocyte imprinting establishment in mice. European Journal of Human Genetics 11 493-496. (doi:10.1038/sj.ejhg.5200990)

Khoueiry R, Ibala-Rhomdane S, Mery L, Blachere T, Guerin JF, Lornage J \& Lefevre A 2008 Dynamic CpG methylation of the KCNQ1OT1 gene during maturation of human oocytes. Journal of Medical Genetics 45 583-588. (doi:10.1136/jmg.2008.057943)

Kobayashi H, Sato A, Otsu E, Hiura H, Tomatsu C, Utsunomiya T, Sasaki H, Yaegashi N \& Arima T 2007 Aberrant DNA methylation of imprinted loci in sperm from oligospermic patients. Human Molecular Genetics 16 2542-2551. (doi:10.1093/hmg/ddm187)
Kobayashi H, Hiura H, John RM, Sato A, Otsu E, Kobayashi N, Suzuki R, Suzuki F, Hayashi C, Utsunomiya T et al. 2009 DNA methylation errors at imprinted loci after assisted conception originate in the parental sperm. European Journal of Human Genetics 17 1582-1591. (doi:10.1038/ejhg. 2009.68)

Kobayashi H, Sakurai T, Imai M, Takahashi N, Fukuda A, Yayoi O, Sato S, Nakabayashi K, Hata K, Sotomaru Y et al. 2012 Contribution of intragenic DNA methylation in mouse gametic DNA methylomes to establish oocyte-specific heritable marks. PLoS Genetics 8 e1002440. (doi:10.1371/journal.pgen.1002440)

Krausz C 2011 Male infertility: pathogenesis and clinical diagnosis. Best Practice \& Research. Clinical Endocrinology \& Metabolism 25 271-285. (doi:10.1016/j.beem.2010.08.006)

Lepikhov K, Wossidlo M, Arand J \& Walter J 2010 DNA methylation reprogramming and DNA repair in the mouse zygote. International Journal of Developmental Biology 54 1565-1574. (doi:10.1387/ijdb. $103206 \mathrm{kl})$

Li T, Vu TH, Ulaner GA, Littman E, Ling JQ, Chen HL, Hu JF, Behr B, Giudice L \& Hoffman AR 2005 IVF results in de novo DNA methylation and histone methylation at an Igf2-H19 imprinting epigenetic switch. Molecular Human Reproduction 11 631-640. (doi:10.1093/molehr/ gah230)

Li X, Ito M, Zhou F, Youngson N, Zuo X, Leder P \& Ferguson-Smith AC 2008 A maternal-zygotic effect gene, Zfp57, maintains both maternal and paternal imprints. Developmental Cell 15 547-557. (doi:10.1016/j. devcel.2008.08.014)

Li L, Zheng P \& Dean J 2010 Maternal control of early mouse development. Development 137 859-870. (doi:10.1242/dev.039487)

Lidegaard O, Pinborg A \& Andersen AN 2005 Imprinting diseases and IVF: Danish National IVF cohort study. Human Reproduction 20 950-954. (doi:10.1093/humrep/deh714)

Lim D, Bowdin SC, Tee L, Kirby GA, Blair E, Fryer A, Lam W, Oley C, Cole T, Brueton LA et al. 2009 Clinical and molecular genetic features of Beckwith-Wiedemann syndrome associated with assisted reproductive technologies. Human Reproduction 24 741-747. (doi:10.1093/humrep/ den406)

Liu K \& Case A 2011 Advanced reproductive age and fertility. Journal of Obstetrics and Gynaecology 33 1165-1175.

Lopes FL, Fortier AL, Darricarrere N, Chan D, Arnold DR \& Trasler JM 2009 Reproductive and epigenetic outcomes associated with aging mouse oocytes. Human Molecular Genetics 18 2032-2044. (doi:10.1093/hmg/ddp127)

Ludwig M, Katalinic A, Gross S, Sutcliffe A, Varon R \& Horsthemke B 2005 Increased prevalence of imprinting defects in patients with Angelman syndrome born to subfertile couples. Journal of Medical Genetics 42 289-291. (doi:10.1136/jmg.2004.026930)

Maher ER, Brueton LA, Bowdin SC, Luharia A, Cooper W, Cole TR, Macdonald F, Sampson JR, Barratt CL, Reik W et al. 2003 BeckwithWiedemann syndrome and assisted reproduction technology (ART). Journal of Medical Genetics 40 62-64. (doi:10.1136/jmg.40.1.62)

Mann MR, Lee SS, Doherty AS, Verona RI, Nolen LD, Schultz RM \& Bartolomei MS 2004 Selective loss of imprinting in the placenta following preimplantation development in culture. Development 131 3727-3735. (doi:10.1242/dev.01241)

Manning M, Lissens W, Bonduelle M, Camus M, De Rijcke M, Liebaers I \& Van Steirteghem A 2000 Study of DNA-methylation patterns at chromosome $15 q 11-q 13$ in children born after ICSI reveals no imprinting defects. Molecular Human Reproduction 6 1049-1053. (doi:10.1093/molehr/6.11.1049)

Manning M, Lissens W, Liebaers I, Van Steirteghem A \& Weidner W 2001 Imprinting analysis in spermatozoa prepared for intracytoplasmic sperm injection (ICSI). International Journal of Andrology 24 87-94. (doi:10.1046/j.1365-2605.2001.00274.x)

Market-Velker BA, Fernandes AD \& Mann MR 2010a Side-by-side comparison of five commercial media systems in a mouse model: suboptimal in vitro culture interferes with imprint maintenance. Biology of Reproduction 83 938-950. (doi:10.1095/biolreprod.110.085480)

Market-Velker BA, Zhang L, Magri LS, Bonvissuto AC \& Mann MR 2010b Dual effects of superovulation: loss of maternal and paternal imprinted methylation in a dose-dependent manner. Human Molecular Genetics 19 36-51. (doi:10.1093/hmg/ddp465) 
Market Velker BA, Denomme MM \& Mann MR 2012 Loss of genomic imprinting in mouse embryos with fast rates of preimplantation development in culture. Biology of Reproduction 86 143. (doi:10.1095/ biolreprod.111.096602)

Marques CJ, Costa P, Vaz B, Carvalho F, Fernandes S, Barros A \& Sousa M 2008 Abnormal methylation of imprinted genes in human sperm is associated with oligozoospermia. Molecular Human Reproduction 14 67-74. (doi:10.1093/molehr/gam093)

Messerschmidt DM, de Vries W, Ito M, Solter D, Ferguson-Smith A \& Knowles BB 2012 Trim28 is required for epigenetic stability during mouse oocyte to embryo transition. Science 335 1499-1502. (doi:10.1126/ science.1216154)

Minor A, Chow V \& Ma S 2011 Aberrant DNA methylation at imprinted genes in testicular sperm retrieved from men with obstructive azoospermia and undergoing vasectomy reversal. Reproduction 141 749-757. (doi:10.1530/REP-11-0008)

Nakamura T, Liu YJ, Nakashima H, Umehara H, Inoue K, Matoba S, Tachibana M, Ogura A, Shinkai Y \& Nakano T 2012 PGC7 binds histone $\mathrm{H} 3 \mathrm{~K} 9 \mathrm{me} 2$ to protect against conversion of $5 \mathrm{mC}$ to $5 \mathrm{hmC}$ in early embryos. Nature 486 415-419. (doi:10.1038/nature11093)

Oliver VF, Miles HL, Cutfield WS, Hofman PL, Ludgate JL \& Morison IM 2012 Defects in imprinting and genome-wide DNA methylation are not common in the in vitro fertilization population. Fertility and Sterility 97 147-153.e7. (doi:10.1016/j.fertnstert.2011.10.027)

Orstavik KH, Eiklid K, van der Hagen CB, Spetalen S, Kierulf K, Skjeldal O \& Buiting K 2003 Another case of imprinting defect in a girl with Angelman syndrome who was conceived by intracytoplasmic semen injection. American Journal of Human Genetics 72 218-219. (doi:10.1086/346030)

Pacheco SE, Houseman EA, Christensen BC, Marsit CJ, Kelsey KT, Sigman M \& Boekelheide K 2011 Integrative DNA methylation and gene expression analyses identify DNA packaging and epigenetic regulatory genes associated with low motility sperm. PLOS ONE 6 e20280. (doi:10.1371/journal.pone.0020280)

Patrushev LI \& Minkevich IG 2008 The problem of the eukaryotic genome size. Biochemistry 73 1519-1552. (doi:10.1134/S0006297908130117)

Rivera RM, Stein P, Weaver JR, Mager J, Schultz RM \& Bartolomei MS 2008 Manipulations of mouse embryos prior to implantation result in aberrant expression of imprinted genes on day 9.5 of development. Human Molecular Genetics 17 1-14. (doi:10.1093/hmg/ddm280)

Rossignol S, Steunou V, Chalas C, Kerjean A, Rigolet M, ViegasPequignot E, Jouannet P, Le Bouc Y \& Gicquel C 2006 The epigenetic imprinting defect of patients with Beckwith-Wiedemann syndrome born after assisted reproductive technology is not restricted to the 11 p15 region. Journal of Medical Genetics 43 902-907. (doi:10.1136/ jmg.2006.042135)

Saitou M, Kagiwada S \& Kurimoto K 2012 Epigenetic reprogramming in mouse pre-implantation development and primordial germ cells. Development 139 15-31. (doi:10.1242/dev.050849)

Sasaki H, Ferguson-Smith AC, Shum AS, Barton SC \& Surani MA 1995 Temporal and spatial regulation of H19 imprinting in normal and uniparental mouse embryos. Development 121 4195-4202.

Sato A, Otsu E, Negishi H, Utsunomiya T \& Arima T 2007 Aberrant DNA methylation of imprinted loci in superovulated oocytes. Human Reproduction 22 26-35. (doi:10.1093/humrep/del316)

Sato A, Hiura H, Okae H, Miyauchi N, Abe Y, Utsunomiya T, Yaegashi N \& Arima T 2011 Assessing loss of imprint methylation in sperm from subfertile men using novel methylation polymerase chain reaction Luminex analysis. Fertility and Sterility 95 129-134, 134.e1-4. (doi:10.1016/ j.fertnstert.2010.06.076)

Sauvat F, Capito C, Sarnacki S, Poirot C, Bachelot A, Meduri G, Dandolo L \& Binart N 2008 Immature cryopreserved ovary restores puberty and fertility in mice without alteration of epigenetic marks. PLOS ONE 3 e1972. (doi:10.1371/journal.pone.0001972)

Savage T, Peek J, Hofman PL \& Cutfield WS 2011 Childhood outcomes of assisted reproductive technology. Human Reproduction 26 2392-2400. (doi:10.1093/humrep/der212)
Shi W \& Haaf T 2002 Aberrant methylation patterns at the two-cell stage as an indicator of early developmental failure. Molecular Reproduction and Development 63 329-334. (doi:10.1002/mrd.90016)

Shi X, Ni Y, Zheng H, Chen S, Zhong M, Wu F, Xia R \& Luo Y 2011 Abnormal methylation patterns at the IGF2/H19 imprinting control region in phenotypically normal babies conceived by assisted reproductive technologies. European Journal of Obstetrics \& Gynecology and Reproductive Biology 158 52-55. (doi:10.1016/j.ejogrb.2011.04.001)

Smallwood SA, Tomizawa S, Krueger F, Ruf N, Carli N, Segonds-Pichon A, Sato S, Hata K, Andrews SR \& Kelsey G 2011 Dynamic CpG island methylation landscape in oocytes and preimplantation embryos. Nature Genetics 43 811-814. (doi:10.1038/ng.864)

Strawn EY Jr, Bick D \& Swanson A 2010 Is it the patient or the IVF? Beckwith-Wiedemann syndrome in both spontaneous and assisted reproductive conceptions Fertility and Sterility 94 754.e1-2. (doi:10.1016/ j.fertnstert.2010.01.067)

Sutcliffe AG, Peters CJ, Bowdin S, Temple K, Reardon W, Wilson L, Clayton-Smith J, Brueton LA, Bannister W \& Maher ER 2006 Assisted reproductive therapies and imprinting disorders - a preliminary British survey. Human Reproduction 21 1009-1011. (doi:10.1093/humrep/ dei405)

Suzuki J Jr, Therrien J, Filion F, Lefebvre R, Goff AK \& Smith LC 2009 In vitro culture and somatic cell nuclear transfer affect imprinting of SNRPN gene in pre- and post-implantation stages of development in cattle. BMC Developmental Biology 9 9. (doi:10.1186/1471-213X-9-9)

Tierling S, Souren NY, Gries J, Loporto C, Groth M, Lutsik P, Neitzel H, Utz-Billing I, Gillessen-Kaesbach G, Kentenich H et al. 2010 Assisted reproductive technologies do not enhance the variability of DNA methylation imprints in human. Journal of Medical Genetics 47 371-376. (doi:10.1136/jmg.2009.073189)

Trapphoff T, El Hajj N, Zechner U, Haaf T \& Eichenlaub-Ritter U 2010 DNA integrity, growth pattern, spindle formation, chromosomal constitution and imprinting patterns of mouse oocytes from vitrified pre-antral follicles. Human Reproduction 25 3025-3042. (doi:10.1093/humrep/ deq278)

Turan N, Katari S, Gerson LF, Chalian R, Foster MW, Gaughan JP, Coutifaris C \& Sapienza C 2010 Inter- and intra-individual variation in allele-specific DNA methylation and gene expression in children conceived using assisted reproductive technology. PLoS Genetics 6 e1001033. (doi:10.1371/journal.pgen.1001033)

de Waal E, Yamazaki Y, Ingale P, Bartolomei MS, Yanagimachi R \& McCarrey JR 2012 Gonadotropin stimulation contributes to an increased incidence of epimutations in ICSI-derived mice. Human Molecular Genetics [in press]. (doi:10.1093/hmg/dds287)

Wong EC, Hatakeyama C, Robinson WP \& Ma S 2011 DNA methylation at H19/IGF2 ICR1 in the placenta of pregnancies conceived by in vitro fertilization and intracytoplasmic sperm injection. Fertility and Sterility 95 2524-2526.e1-3. (doi:10.1016/j.fertnstert.2011.05.047)

Wright K, Brown L, Brown G, Casson P \& Brown S 2011 Microarray assessment of methylation in individual mouse blastocyst stage embryos shows that in vitro culture may have widespread genomic effects. Human Reproduction 26 2576-2585. (doi:10.1093/humrep/der201)

Young LE, Fernandes K, McEvoy TG, Butterwith SC, Gutierrez CG, Carolan C, Broadbent PJ, Robinson JJ, Wilmut I \& Sinclair KD 2001 Epigenetic change in IGF2R is associated with fetal overgrowth after sheep embryo culture. Nature Genetics 27 153-154. (doi:10.1038/84769)

Zegers-Hochschild F, Adamson GD, de Mouzon J, Ishihara O, Mansour R, Nygren K, Sullivan E \& Vanderpoel S 2009 International Committee for Monitoring Assisted Reproductive Technology (ICMART) and the World Health Organization (WHO) revised glossary of ART terminology. Fertility and Sterility 92 1520-1524. (doi:10.1016/j.fertnstert.2009.09.009)

Received 20 June 2012

First decision 20 August 2012

Accepted 5 September 2012 